\title{
Pulmonary Nano-Drug Delivery Systems for Lung Cancer: Current Knowledge and Prospects
}

\author{
Madumani Amararathna', Kerry Goralski ${ }^{2}$, David W. Hoskin ${ }^{3,4}$, H. P. Vasantha Rupasinghe ${ }^{1,3 *}$ \\ 'Department of Plant, Food, and Environmental Sciences, Faculty of Agriculture, Dalhousie University, Rm 219-C, Cox Institute Building, 50 Pictou Rd. PO Box \\ 550 , Truro, NS, B2N 5E3, Canada. \\ ${ }^{2}$ College of Pharmacy and Department of Pharmacology, Dalhousie University, Halifax, NS B3H 4R2, Canada. \\ ${ }^{3}$ Department of Pathology, Faculty of Medicine, Dalhousie University, Halifax, NS B3H 4R2, Canada. \\ ${ }^{4}$ Department of Microbiology and Immunology, Faculty of Medicine, Dalhousie University, Halifax, NS B3H 4R2, Canada.
}

Article Info

\section{Article Notes}

Received: February 3, 2019

Accepted: March 11, 2019

\section{${ }^{*}$ Correspondence:}

Dr. H.P. Vasantha Rupasinghe, Department of Plant,

Food, and Environmental Sciences, Faculty of Agriculture,

Dalhousie University, Rm 219-C, Cox Institute Building,

50 Pictou Rd. PO Box 550, Truro, NS, B2N 5E3, Canada;

Telephone No: 902.893.6623;

Email: vrupasinghe@dal.ca.

(c) 2019 Rupasinghe HPV. This article is distributed under the terms of the Creative Commons Attribution 4.0 International License.

\section{Keywords:}

Nanoparticles

Inhalation

Pharmacology

Permeability

PEGylation

Local drug delivery

\section{Abstract}

Treatment complexities and the cytotoxicity of anticancer drugs to normal cells often results in therapeutic failure. Biodegradable nanoparticles have gained attention as drug carriers due to their physicochemical characteristics. Nanoparticles are able to encapsulate anticancer drugs and deliver them to target malignant cells while sparing normal cells. Since lung cancer usually arises in lung epithelium, localized drug delivery could be an alternative strategy to effectively treat this disease. Encapsulation of lung cancer drugs in nanoparticles may facilitate intact drug delivery, avoid first-pass metabolism, and reduce cytotoxicity to normal cells, as well as being attractive to patients. However, nanoparticles should be formulated in such a way as to facilitate entrance, deposition, retention, and permeability on targeted lung tissues and escape mucociliary clearance and phagocytosis. Additionally, the patient's diversity related to lung cancer type, stage of disease, and physical fitness should be considered when formulating a nanocarrier and a delivery device. The potential of localized drug delivery for lung cancer using nanoparticles is reviewed here.

\section{Abbreviations}

PLGA, poly(lactide-co-glycolide); MRP1, multidrug resistance associated protein 1; GST, glutathione-s-transferase; NAT, $\mathrm{N}$-acetyltransferease; SULT, sulfotransferases; TRAIL, tumor necrosis factor-related apoptosis-inducing ligand.

\section{Introduction}

Lung cancer is the most commonly diagnosed cancer $(11.6 \%$ of all the cases), and the leading cause for cancer deaths $(18.4 \%$ of all cancer deaths) among both men and women worldwide ${ }^{1}$. Lung cancer is a heterogeneous disease that arises when genetic and epigenetic alterations happen in lung epithelium ${ }^{2}$. Most lung tumors are the result of frequent exposure to tobacco smoke. However, exposure to exogenous carcinogens, such as diesel exhaust, radon, household fumes and radiation in domestic and occupational environments, has been estimated to cause $10-25 \%$ of lung cancers in non-smokers ${ }^{3,4}$. Based on clinical and therapeutic characteristics, lung cancer is broadly divided into small cell lung cancer (SCLC) and non-small cell lung cancer (NSCLC). NSCLC is further divided into squamous cell carcinoma (SCC), adenocarcinoma (ADC), and large cell carcinoma (LCC). SCLC usually found perihilar on the main bronchus while SCC initiated on main stem lobar or segmental bronchi. ADC and LCC emerge on peripheral lung tissues ${ }^{5-7}$. 
The selection of the treatment regimen for lung cancer depends on the stage of cancer and the patient's physical condition. Generally, all the stages of SCLC are treated with chemotherapy or chemoradiotherapy since surgery is inadequate to control the disease due to the rapid doubling and metastatic characteristics of the malignant cells ${ }^{8}$. Surgical resection is the frequent treatment of choice for stage 1 NSCLC as the tumor is often localized to one area of the lung and has not spread to draining lymph nodes. However, for stage 2 and 3 NSCLC, chemotherapy or chemoradiotherapy, post surgery or neoadjuvant chemotherapy followed by surgery is given, depending on the extent of tumor invasion into the chest cavity. Neoadjuvant chemotherapy shrinks the tumors and controls distal occurrence to nearby tissues. Chemoradiotherapy is the only treatment option available for stage 4 lung cancer patients as this ensures systemic drug delivery to metastatic lesions ${ }^{9-11}$.

Current lung cancer treatments often cause adverse short-term and long-term side effects, including nausea, ulcers, cardiotoxicity, increased risk of developing other cancers, cytotoxicity to healthy cells, and induction of a broad spectrum of degenerative diseases ${ }^{12}$. For example, cisplatin, a drug commonly given to lung, breast and ovarian cancer patients, and doxorubicin, used to treat breast cancer, show nephrotoxicity $(20-30 \%)$ and cardiotoxicity (3-20\%), respectively ${ }^{13,14}$. Even if lung cancer is properly treated, recurrence of the disease is common due to the presence of occult micro-metastatic cancer cells, development of drug resistance and enrichment of cancer stem cells; this results in a poor survival rate among lung cancer patients ${ }^{15,16}$. Table 1 presents the cytotoxic effects of common lung cancer therapeutics.

Dose-limiting cytotoxicity of anticancer drugs compromises treatment efficacy resulting in poor prognosis and, sometimes, loss of life. For example, a clinical study conducted in China has shown that etoposide and cisplatin cause adverse drug reactions such as neutropenia (71.9\%), leukopenia $(53.1 \%)$, and thrombocytopenia $(18.8 \%)$ in advanced SCLC patients who had a median survival of 15.8 months $^{17}$. Clinical implementation of an aggressive chemotherapy regimen of bevacizumab $(15 \mathrm{mg} / \mathrm{kg})$, cisplatin $\left(75 \mathrm{mg} / \mathrm{m}^{2}\right)$ and gemcitabine $\left(1250 \mathrm{mg} / \mathrm{m}^{2}\right)$ for six cycles followed by bevacizumab alone only results in an additional 2.5 months of progression-free survival and overall survival compared with pemetrexed $\left(500 \mathrm{mg} / \mathrm{m}^{2}\right)$

Table 1. Current lung cancer therapeutics, their mechanism of action and common side effects.

\begin{tabular}{|c|c|c|c|c|}
\hline Drug & FDA approval & Mechanism of action in lung cancer & Side effects & Reference \\
\hline \multicolumn{5}{|c|}{ Adenocarcinoma } \\
\hline Cisplatin & 1978 & $\begin{array}{l}\text { Induction of oxidative stress } \\
\text { Formation of DNA adducts } \\
\text { Induction of apoptosis }\end{array}$ & $\begin{array}{l}\text { Nephrotoxicity } \\
\text { Ototoxicity } \\
\text { Neurotoxicity }\end{array}$ & 86 \\
\hline Carboplatin & 1989 & $\begin{array}{l}\text { Formation of interstrand and intrastrand DNA cross- } \\
\text { links } \\
\text { Inhibition of DNA synthesis }\end{array}$ & $\begin{array}{l}\text { Anemia } \\
\text { Neutropenia } \\
\text { Thrombocytopenia }\end{array}$ & 87 \\
\hline Crizotinib & 2011 & $\begin{array}{l}\text { Inhibition of ALK, hepatocyte growth factor receptor } \\
\text { Inhibition of ROS1 } \\
\text { Suppression of growth } \\
\text { Induction of apoptosis }\end{array}$ & $\begin{array}{l}\text { Pneumonitis } \\
\text { Bradycardia } \\
\text { Vision disorders }\end{array}$ & 87 \\
\hline Atezolizumab & 2016 & $\begin{array}{l}\text { Inhibition of the interaction between PD-L1 and } \\
\text { PD-1 receptor } \\
\text { Induction of T-cell antitumor activity }\end{array}$ & $\begin{array}{l}\text { Fatigue } \\
\text { Diarrhea } \\
\text { Nausea }\end{array}$ & 88 \\
\hline Bevacizumab & 2006 & $\begin{array}{l}\text { Fusion with VEGF } \\
\text { Inhibition of VEGF activity } \\
\text { Prevention of endothelial cell proliferation } \\
\text { Suppression of angiogenesis }\end{array}$ & $\begin{array}{l}\text { Hypertension } \\
\text { Wound healing complications }\end{array}$ & 89 \\
\hline Ceritinib & 2006 & $\begin{array}{l}\text { Inhibition of autophosphorylation of ALK, insu- } \\
\text { lin-like growth factor } 1 \text { receptor and ROS1 }\end{array}$ & $\begin{array}{l}\text { Abdominal pain } \\
\text { Diarrhea } \\
\text { Hyperglycemia }\end{array}$ & 90 \\
\hline \multicolumn{5}{|c|}{ Squamous cell carcinoma } \\
\hline Paclitaxel & 2012 & $\begin{array}{l}\text { Fusion with } \beta \text {-tubulin } \\
\text { Stabilization of microtubules } \\
\text { Inhibition of cell cycle at mitotic phase }\end{array}$ & $\begin{array}{l}\text { Neutropenia, } \\
\text { Nausea and vomiting } \\
\text { Arthralgia }\end{array}$ & 91 \\
\hline Methotrexate & 2014 & $\begin{array}{l}\text { Inhibition of the synthesis of purine nucleotides } \\
\text { Suppression of DNA synthesis } \\
\text { Inhibition of cell proliferation }\end{array}$ & $\begin{array}{l}\text { Hepatotoxicity } \\
\text { Osteonecrosis } \\
\text { Soft tissue necrosis }\end{array}$ & 86 \\
\hline
\end{tabular}

ALK, anaplastic lymphoma kinase; PD-L1, programmed death ligand 1; PD-1, programmed death 1; VEGF, vascular endothelial growth factor, VEGF; ROS1, a gene encoding receptor tyrosine kinase (RTK) of the insulin receptor family 
plus cisplatin $\left(75 \mathrm{mg} / \mathrm{m}^{2}\right.$ ) for 6 cycles in NSCLC patients with advanced disease ${ }^{18}$. Most lung cancer therapeutics are administered via intravenous injections. Switching to the non-invasive oral delivery of chemotherapeutics is desirable but challenging due to the potential for poor drug solubility, low chemical stability and permeability, irritation of the gastrointestinal (GI) tract, and phase I and phase II metabolism in the GI tract and hepatic tissues. For instance, oral administration reduces the therapeutic efficacy of the taxanes, paclitaxel, and docetaxel, due to their higher affinity for drug transporters (P-glycoprotein), low drug solubility and metabolism by cytochrome P450 (CYP3A) enzymes ${ }^{19}$. As previously reviewed, inhalation facilitates non-invasive local and systemic drug delivery for treating many respiratory diseases, including cancer $^{20,21}$. Direct delivery of chemotherapeutics to lung tissues may cause toxicities, poor delivery efficiency, multidrug resistance, and severe side effects as it does not permit selective delivery on cancer cells. The encapsulation of chemotherapeutics in nanocarriers, such as liposomes, dendrimers, micelles, minimizes cytotoxicity, enables targeted drug delivery, sustained drug release and avoids drug resistance. Codelivery of gefitinib and vorinostat in hyaluronan-based copolymer nanoparticles minimizes the hepatic toxicity, enhances persistent drug release and inhibits orthotopic lung tumors in mice compared to the free drugs ${ }^{22}$. Conjugating the growth factor, folic acid, on dendrimers improves targeted co-delivery of siRNA and cisplatin resulting in apoptosis of the folate receptor overexpressing H1299 lung cancer cells with negligible toxicity towards MRC9 lung fibroblasts ${ }^{23}$. Liu and colleagues have demonstrated the potential of using liposomal nanoparticles in effectively delivering 1,25-dihydroxy vitamin D3, which promotes epithelial differentiation and inhibits NSCLC, into erlotinib resistant HCC827 lung cancer cells ${ }^{24}$.

It is, therefore, necessary to understand the benefits of using nanocarriers in effectively delivering chemotherapeutics with minimum systemic cytotoxicity to normal cells. This review discusses nanotechnology-based drug carriers and their potential for delivering localized cancer treatments to target lung cancer with minimal adverse side effects.

\section{Pulmonary drug delivery, absorption, metabolism, and clearance}

\section{Drug delivery and distribution}

The respiratory system coordinates with the circulatory system to supply oxygen from the outside environment to cells of the body and remove carbon dioxide from the body. The respiratory system is broadly divided into two sections; the upper respiratory tract consisting of the nose, nasal cavity and pharynx; and the lower respiratory tract consisting of the larynx, trachea, bronchi (airway region), and the alveoli absorption region. Inhaled drugs can deposit via impaction, sedimentation, interception or diffusion, depending on the particle size, airflow rate and location in the respiratory system. Table 2 and Figure 1 present the effects of particle size on site of deposition within the respiratory tract. Most particles greater than $10 \mu \mathrm{m}$ are deposited by impaction the oropharyngeal region and are subsequently swallowed, resulting in poor bioavailability ${ }^{25}$. Micromolecules, $<5 \mu \mathrm{m}$ size, can reach the deep peripheral lung alveoli, and hence may be a very good candidate for systemic drug delivery via the respiratory route. Most particles between $0.1-1 \mu \mathrm{m}$ in size are exhaled from the lung tissues ${ }^{26,27}$. However, small particles $(<0.1$ $\mu \mathrm{M},<100 \mathrm{~nm}$ ) are quickly deposited on lung surface by Brownian motion, ${ }^{28}$ and could, therefore, be effective as drug carriers. For example, $20 \mathrm{~nm}$ size silver nanoparticles are evenly distributed and deposited by diffusion among all five lobes of rat lungs after one day or five days nose only exposure $^{29}$. In contrast, intratracheal inhalation of $20 \mathrm{~nm}$ gold nanoparticles results, for the most part, in deposition in the caudal lungs of Wistar rats. Some of them are deposited on the airway epithelium and alveoli as well ${ }^{30}$. As Yang et al suggested, lung biodistribution of nanoparticles $(18-480 \mathrm{~nm})$ is determined by means of the delivery method. Intratracheal instillation encourages more central deposition whereas more homogenous central to peripheral deposition is found in ventilator-assisted aerosol inhalation in preclinical experimental models ${ }^{31}$. In humans, 50 - $100 \mathrm{~nm}$ particles are deposited mostly in peripheral airways, and the deposition rate is affected by lung capacity, lung health and breathing depth ${ }^{32}$.

\section{Pulmonary drug absorption}

The large alveolar surface relative to the small airway and alveolar volume provides a good superficial layer for pulmonary drug delivery and absorption ${ }^{33}$. Drug transfer across the lung epithelium occurs by passive diffusion, facilitative and active transport via solute transport carriers that reside on the apical and basolateral surface

Table 2. Particle distribution and deposition in the respiratory system based on their geometric size.

\begin{tabular}{|c|c|c|}
\hline Particle size $(\mu \mathrm{m})$ & Location & Deposition method \\
\hline$>10$ & Oropharyngeal region & Impaction \\
\hline $5-10$ & $\begin{array}{l}\text { Large conducting airways } \\
\text { Oropharyngeal region }\end{array}$ & Inertial impaction \\
\hline $1-5$ & $\begin{array}{l}\text { Small airways } \\
\text { Alveoli }\end{array}$ & $\begin{array}{l}\text { Gravitational sedi- } \\
\text { mentation }\end{array}$ \\
\hline$<3$ & $\begin{array}{l}\text { Lower airways } \\
\text { Alveoli }\end{array}$ & $\begin{array}{l}\text { Sedimentation } \\
\text { Diffusion }\end{array}$ \\
\hline $0.1-1$ & $\begin{array}{l}\text { Airways, lower airways } \\
\text { and alveoli }\end{array}$ & Diffusion \\
\hline$<0.1$ & $\begin{array}{l}\text { Peripheral airways, } \\
\text { alveoli }\end{array}$ & Diffusion \\
\hline$<0.01$ & Upper respiratory region & \\
\hline
\end{tabular}




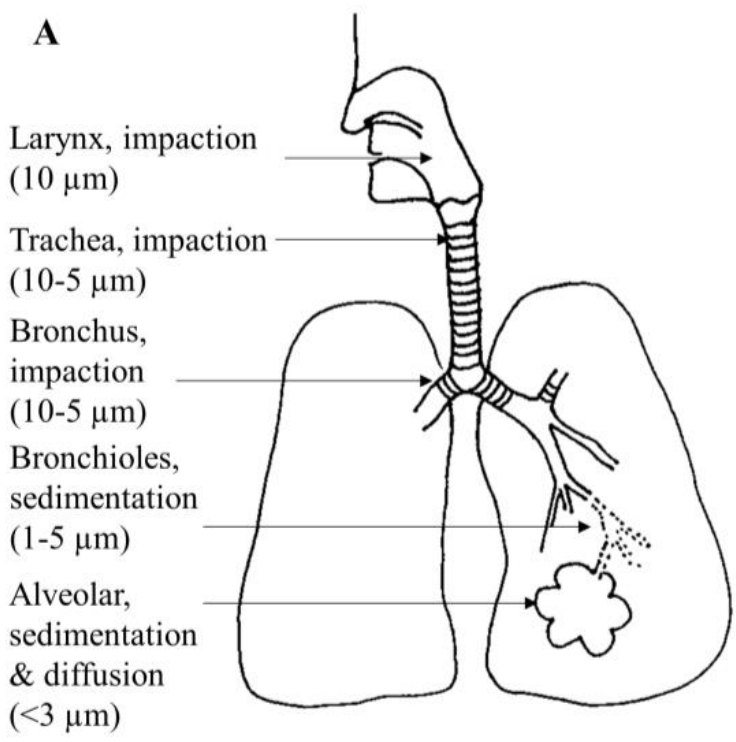

D

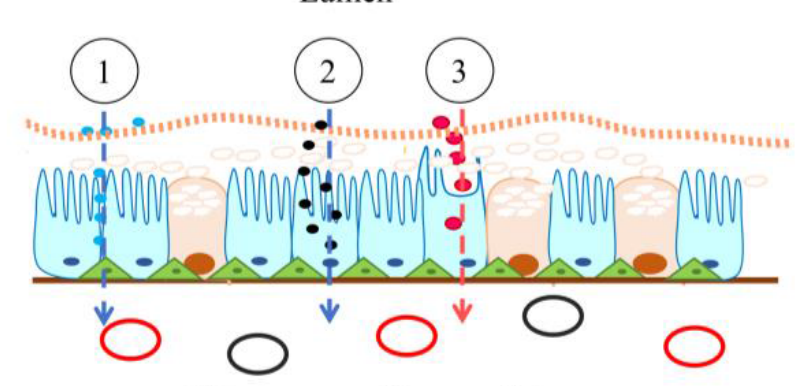

Sub mucosa with vasculature

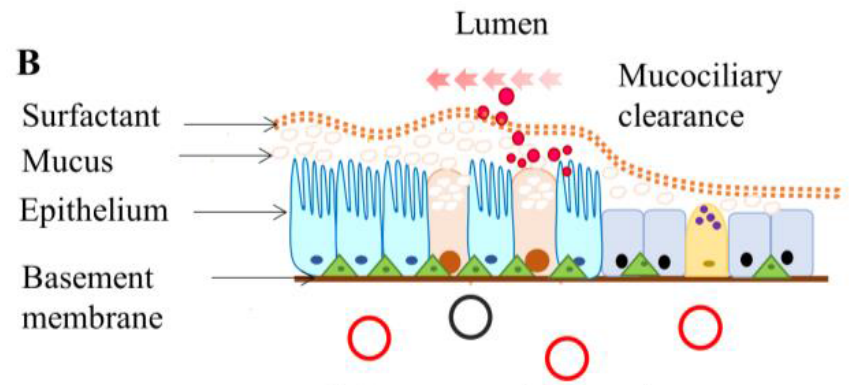

Sub mucosa with vasculature

C

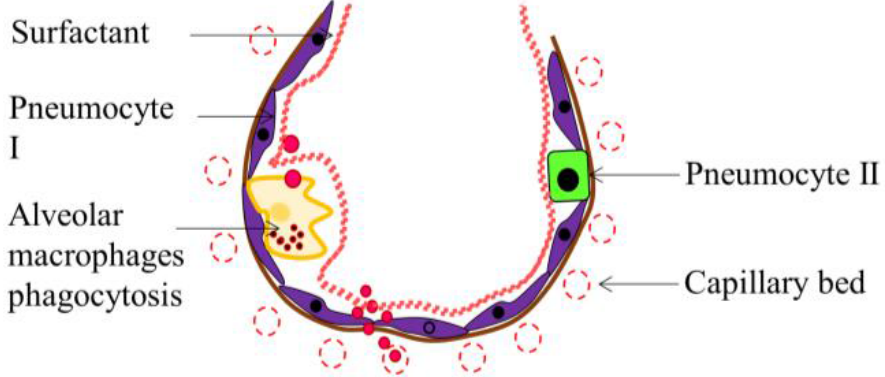

Figure 1: Illustration of respiratory drug delivery, absorption, and clearance. A) The inhaled aerosol drugs deposit in the airway and alveolar tissues, depending on their particle size, by impaction (larger molecules at oropharyngeal and tracheal region), sedimentation (at the central and peripheral lung tissues) and both diffusion and sedimentation (nanoparticles at bronchioles and alveoli). B) Large, poorly soluble, drugs deposited at trachea and bronchus are moved upward by mucociliary beat and end up in the GI tract. However, microparticles can penetrate mucus that lies above the ciliary surface and either reside in it or pass through the airway epithelium. $\mathrm{C}$ ) in the alveolus, alveolar macrophages clear the microparticles through phagocytosis. However, most nano molecules rapidly reach the respiratory vasculature through the thin alveolar and endothelial walls at lung periphery. D) The most common mechanisms of pulmonary drug absorption; 1. Paracellular absorption of most hydrophilic molecules through tight intercellular junctions, 2. Endocytosis of large molecules through membrane-bound receptors, and 3. Transcellular absorption of lipophilic drug molecules through the plasma membrane. Note that illustrations are not drawn according to scale.

of the plasma membrane, and vesicle-mediated transport (Figure 2). The pseudostratified columnar airway epithelium (approximately $60 \mu \mathrm{m}$ thickness) and thin alveolar epithelium ( $0.2 \mu \mathrm{m}$ thickness) enhance the absorption of both hydrophilic and lipophilic drug molecules ${ }^{27}$. Once the drug molecules attach to the surfactant layer, some of them will traverse through and reach the lining fluid and epithelium cells. Hydrophilic drugs absorb through paracellular diffusion (prolongs absorption), while most lipophilic drugs are absorbed via transcellular diffusion. In addition, macromolecules ( $\mathrm{MW}$ is $>40 \mathrm{kDa}$ ) remain on the surface of the lung epithelium for a long time and absorb slowly; in contrast, small molecules (MW $<40 \mathrm{kDa}$ ) can reach blood circulation within a few minutes of inhalation ${ }^{26,34}$.
Drug transport proteins reside on the cytoplasmic membrane of the lung epithelium and are highly localized in bronchial and alveolar regions ${ }^{35}$. The organic cation/ carnitine transporter 1 is located on the luminal side of the airway epithelium and facilitates drug influx into the lung epithelial cells. Multidrug resistance-associated protein 1 (MRP1) is located on the basolateral side of the human bronchial epithelial cells and facilitates drug efflux from the lung epithelial cells ${ }^{35}$. A higher expression level of MRP1 has been found in NSCLC, which mediates resistance to carboplatin and paclitaxel co-treatment, resulting in poor therapeutic effect ${ }^{36}$. Macromolecules, larger than $50 \mathrm{kDa}$ (e.g., albumins), absorb via receptor-mediated 

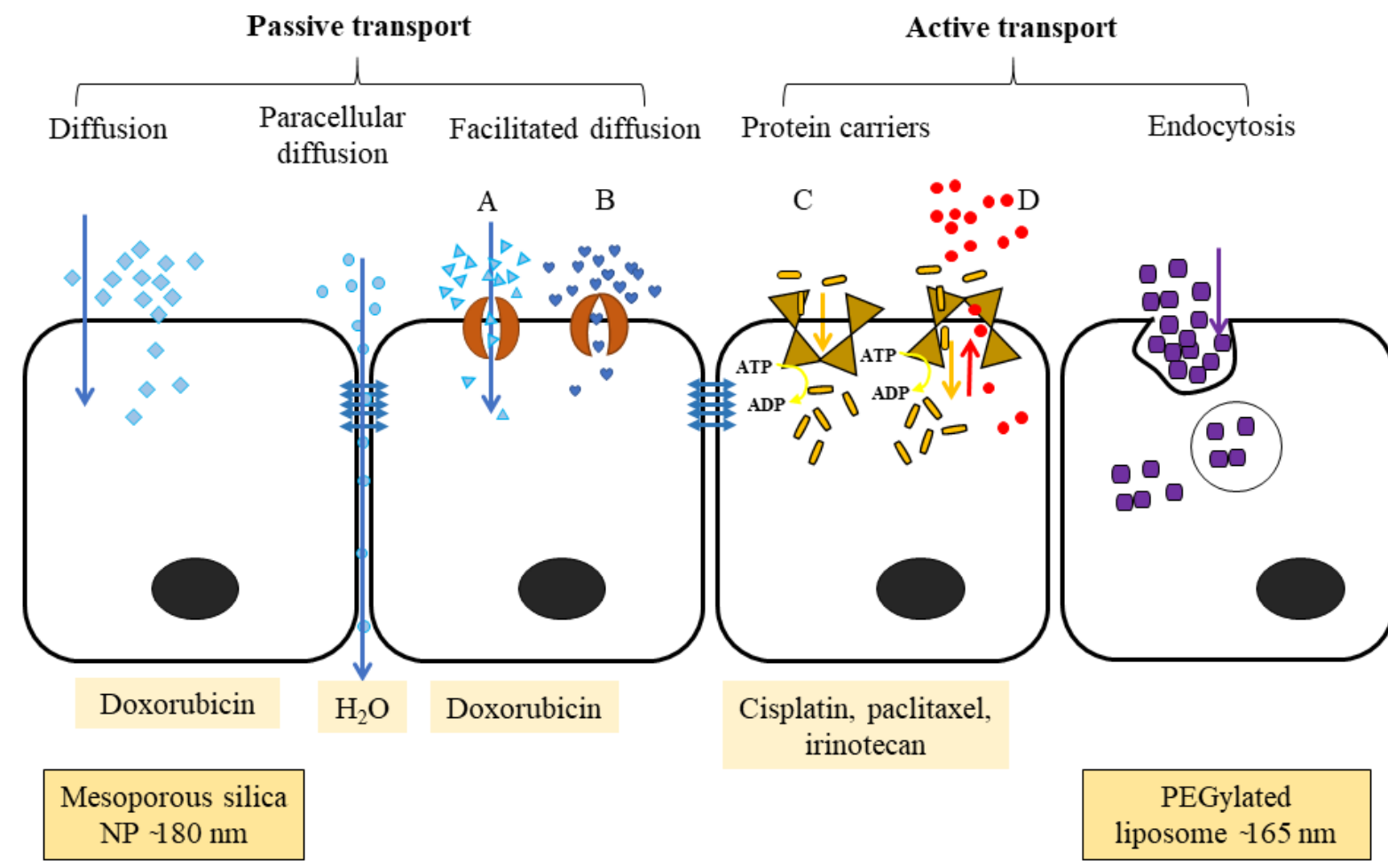

Figure 2: The different ways that molecules are transported across a cellular barrier. Passive transport happens along the concentration gradient. Diffusion is the movement of hydrophobic and non-ionic molecules across the plasma membrane from higher to lower concentration. Paracellular diffusion transports water-soluble molecules through the intercellular space by passing through the tight junction. Facilitated diffusion passes large, ionic or hydrophilic molecules via transmembrane integral proteins; A) protein channel and B) carrier proteins. Active transport needs carrier integral proteins and energy (ATP converted into ADP) to transport large molecules or ions against a concentration gradient. C) Primary active transport uses ATP to move molecules against a concentration gradient. D) Secondary active transport uses an electrochemical gradient generated by the $\mathrm{Na}+/ \mathrm{K}+$ ATPase as an energy source to move molecules against a concentration gradient. Endocytosis is engulfing large molecules such as polar, hydrophilic agents, bacteria, into the cells.

transcytosis ${ }^{37}$. For instance, biotinylated epidermal growth factor on gelatine nanoparticles $(200 \mathrm{~nm})$ shows enhanced cellular uptake compared to non-biotinylated gelatine nanoparticles in A549 adenocarcinoma cells ${ }^{38}$. Similarly, transferrin receptor-mediated DNA uptake via endocytosis was observed by Melguizo et al. in HeLa cells in vitro ${ }^{36}$ (Figure 2). The surface charge is a key determinant of bioavailability and cellular uptake of nanoparticles. $\mathrm{Li}$ and colleagues have demonstrated that surface functionality plays a major role in bioavailability, cellular internalization, and pulmonary toxicity of carbon nanotubes. Anionic nanoparticles (polyetherimide (PEI) surface functionality) have higher cell internalization capability compared to that of the cationic particles (COOH and PEG functionality groups). However, PEInanotubes induce chronic inflammation and fibrosis in murine lungs compared to anionic nanoparticles ${ }^{39}$. Many investigators have reported pulmonary inflammation and induced immune responses after installation of cationic nanoparticles in mouse experimental models and suggested their use as immune vaccines ${ }^{40-42}$. In contrast, installation of negatively charged silver nanoparticles have induces chronic lung inflammation and the infiltration of macrophages, lymphocytes and neutrophils and cardiac toxicity ${ }^{43}$. Cationic nanoparticles are easily internalized into macrophages and dendritic cells ${ }^{42,44}$. Additionally, surface charge density, either negative or positive, is positively correlated with the adsorption and translocation of particles over the respiratory surfactant layer ${ }^{45}$.

\section{Pulmonary drug excretion or clearance}

Once inhaled and deposited, particles and/or drugs are eliminated from the respiratory system via mucociliary clearance, coughing, phagocytosis, systemic absorption or by metabolism in the mucus lining or by lung epithelial cells. Physical and chemical properties of drugs have a major impact on the efficiency of drug clearance. For example, nanoparticles are more rapidly absorbed into the circulatory system compared to macromolecules. Some nanoparticles are cleared by alveolar macrophages (phagocytosis) or slowly move back towards the airway epithelium ${ }^{46}$. Binding of surfactant proteins and lipids to nanoparticles triggers the interaction of macrophages with nanoparticles ${ }^{47}$. In contrast, most of the proteinbased small molecular drugs are rapidly absorbed into the pulmonary circulation intact due to avoidance of 
macrophage clearance ${ }^{26,48}$. Molecules that are trapped in the thick mucus gel layer move upward towards the pharynx by the metachronous beat of airway cilia that extend from the trachea to the terminal bronchioles, after which they are usually routed to the GI tract (Figure 1[B]).

\section{Pulmonary drug metabolism}

Metabolism in lung tissue differs substantially from metabolism in hepatic and GI tissues. The primary detoxification phase I enzymes, cytochrome P450s, have the highest level of expression in hepatocytes and enterocytes but are also expressed in the lungs where they protect against inhaled or ingested xenobiotics, such as cigarette smoke, toxic gas, and air-borne drugs ${ }^{27}$. For example, CYP1B1, CYP2B6, CYP2B7, CYP2E1 CYP2J2, CYP3A5, and CYP1A1 are expressed in human lung tissues and alveolar macrophage ${ }^{27,49}$. These enzymes catalyze the hydroxylation of molecules and enhance their hydrophilicity, thereby facilitating the excretion process. The resulting phase I metabolites gain further hydrophilicity through conjugation to glucuronic acid, glutathione, acetate, and sulfate via the phase II enzymes, UDP glucuronosyl transferase, glutathione-s-transferase (GST), N-acetyltransferase (NAT) and sulfotransferases (SULT), further facilitating their elimination from lung tissues ${ }^{50,51}$. The expression level and pattern of phase I and phase II metabolizing enzymes are low in respiratory epithelium compared to hepatic and GI tissues. Thus, local metabolic deactivation is less of a barrier to systemic drug absorption for inhaled versus orally administered drugs. In contrast, nanoparticles show rapid absorption, less metabolism, and nearly $100 \%$ bioavailability when administered via the respiratory tract. For instance, Chono and colleagues reported an enhanced uptake of insulin-encapsulated dipalmitoyl phosphatidylcholine liposomes $(100 \mathrm{~nm})$ in mouse lungs compared to the administration of free insulin $(5 \mathrm{kDa})^{52}$.

\section{Emerging pharmaceutical technologies: nanoparticles for pulmonary drug delivery}

The pulmonary route of systemic drug delivery has gained recent attention for the treatment of respiratory and non-respiratory diseases. The possibility of direct delivery of smaller doses of the drug to target lung tissues, needleless delivery, and self-operative capability is an attractive option for chemotherapy of lung cancer.

Nanoparticles are submicron sized $(<1 \mu \mathrm{m})$ colloidal particles developed from organic or inorganic materials, including lipids, proteins, natural or artificial polymers, and metals. Drugs can be entrapped in a polymer-based cavity or adsorbed to the surface of the nanoparticle, which can easily extravasate from blood vessels to the target tissue due to the nanoparticle's small size. Based on their structural dimension and chemical nature, nanoparticles are classified as liposomes, micelles, polymer-based nanoparticles, peptide-based nanoparticles, and dendrimers ${ }^{53}$ (Fig. 3). Scientists have also investigated the potential of creating a hybrid of different types of nanoparticles that together will enhance treatment efficiency by delivering dual drugs. For example, $\mathrm{Wu}$ and colleagues have prepared hybrid nanoparticles containing cisplatin and paclitaxel, which are first-line drugs used in the treatment of advanced lung cancer, that consist of a thermosensitive dual drug hydrogel comprised of a cisplatin-containing copolymer, poly(ethylene glycol)-poly( $\varepsilon$-caprolactone)poly(ethylene glycol), and a paclitaxel-loaded polymeric micelle, monomethoxy poly(ethylene glycol)- $\operatorname{poly}(\varepsilon-$ caprolactine). Interestingly, intratumoral injection of the dual drug hydrogel effectively reduces tumor volume, tumor cell proliferation, and microvesicle formation, as well as prolonging the survival of mice xenografted with A549 lung cancer cells ${ }^{54}$. Some researchers have tested alternative approaches to enhancing the penetration of solid lung tumors by nanoparticles. Inhalation of losartan and telmisartan aerosols, prior to intravenous injection of fluorescent polystyrene nanoparticles (200 $\mathrm{nm})$, significantly enhanced the penetration and intratumoral distribution of the nanoparticles by inhibiting transforming growth factor- $\beta 1$ and collagen-I expression ${ }^{55}$. An in vitro study of short-interfering RNA loaded chitosan nanoparticle and co-encapsulation with doxorubicin in poly-L-lactide showed effective silencing of the multidrug resistance gene in H69AR lung cancer, compared to results obtained with non-encapsulated forms ${ }^{56}$.

\section{Liposomes}

Liposomes are typically composed of phospholipids arranged as bilayer vesicles. Depending on their physical structure and size, liposomes are classified as multilamellar vesicles that consist of several concentric bilayers of phospholipid $(1.0-5.0 \mu \mathrm{m})$, and large $(50-100 \mathrm{~nm})$ and small $(30-50 \mathrm{~nm})$ unilamellar vesicles composed of a single bilayer ${ }^{57}$. The phospholipid bilayer enables liposomes to carry both hydrophilic and hydrophobic drugs (Fig. 3) and allows co-delivery of drugs to enhance the therapeutic efficacy of chemotherapeutics ${ }^{58}$. The amount of drug that is encapsulated is determined by both the size and number of concentric bilayers ${ }^{59}$. The circulation life of a liposome depends on its size and surface functionalization. Liposome formulations composed of phospholipids and cholesterol are effective and biocompatible for pulmonary drug delivery as both constituents are inherently present in lung surfactants and plasma membranes ${ }^{20}$. A dual functional liposome, which is decorated with a modified peptide by incorporating 2, 3-dimethyl maleic anhydride and 1, 2-distearoyl-sn-glycero-3-phosphoethanolamine, overcomes the multidrug resistance in lung cancer ${ }^{60}$. The flexibility of modifying liposome surface properties opens novel avenues to develop them as effective drug carriers to directly target cancer. 
Because of sustained release properties over a prolonged period, the possibility of localized drug administration, and biodegradable properties, liposomes have gained traction as an effective and less invasive pulmonary drug delivery system. For instance, Liu and colleagues found that liposome-encapsulated ciprofloxacin, an antibiotic used to treat respiratory infections, exhibits increased bioavailability, enhanced localized drug delivery, inhibits bacterial growth and reduces lung tissue irritation and systemic drug concentration ${ }^{61}$. The evidence in favor of using liposomes as a pulmonary anticancer drug delivery vehicle is presented in Table 3.

Table 3. Evidence supporting the use of nano-encapsulated chemotherapeutics for lung cancer treatment compared to the free drugs.

\begin{tabular}{|c|c|c|c|c|c|}
\hline Drug & Subject & Dose & Adverse effects & Pharmacological effects & Reference \\
\hline \multicolumn{6}{|l|}{ Liposomes } \\
\hline Paclitaxel & $\begin{array}{l}\text { Phase I } \\
\text { human }\end{array}$ & $\begin{array}{l}\text { Intrapleural } 125 \mathrm{mg} / \\
\mathrm{m}^{2}\end{array}$ & $\begin{array}{l}\text { Compared to free drug, no } \\
\text { reported cardiovascular toxicity, } \\
\text { anaphylaxis, neurotoxicity, and } \\
\text { minimum hepatotoxicity }\end{array}$ & $\begin{array}{l}\text { Sustained release of drug in lung tissue } \\
\text { Lowered plasma drug concentration } \\
\text { Reduced excretory speed. }\end{array}$ & 92 \\
\hline $\begin{array}{l}\text { Docetaxel and } \\
\text { BCL2-siRNA }\end{array}$ & Mice & Injection of $5 \mathrm{mg} / \mathrm{kg}$ & No toxicity & $\begin{array}{l}\text { Synergistically reduced tumor volume and size, } \\
\text { increased survival rate (100\%) compared to } \\
\text { free drug and liposome-docetaxel } \\
\text { Sustained drug release }\end{array}$ & 93 \\
\hline Paclitaxel & Mice & $\begin{array}{l}\text { Intravenous } 7.5 \mathrm{mg} / \\
\mathrm{kg}\end{array}$ & No systemic toxicity & $\begin{array}{l}\text { Reduced tumor volume } \\
\text { Induced apoptosis } \\
\text { Suppressed cell proliferation } \\
\text { Incorporation of peptide increased target drug } \\
\text { delivery }\end{array}$ & 60 \\
\hline $\begin{array}{l}\text { Dexamethasone } \\
\text { and docetaxel }\end{array}$ & Mice & $\begin{array}{l}\text { Intravenous } 8 \text { and } \\
4 \mathrm{mg} / \mathrm{kg} \text { docetaxel } \\
\text { and dexamethasone, } \\
\text { respectively }\end{array}$ & $\begin{array}{l}\text { Low toxicity compared to the } \\
\text { combination of free drugs }\end{array}$ & Prevented lung tumor metastasis & 58 \\
\hline $\begin{array}{l}\text { Actinomycin D + } \\
\text { TRAIL }\end{array}$ & Mice & $\begin{array}{l}\text { Intravenous } 0.06 \text { and } \\
0.6 \mathrm{mg} / \mathrm{kg} \text {, respec- } \\
\text { tively }\end{array}$ & $\begin{array}{l}\text { Reduced weight regain after } \\
\text { completion of treatments }\end{array}$ & $\begin{array}{l}\text { Synergistically delayed and reduced tumor } \\
\text { formation and size compared to individual } \\
\text { liposomes }\end{array}$ & 94 \\
\hline Vinblastine & Mice & $\begin{array}{l}\text { Intravenous, } 0.5 \\
\mathrm{mg} / \mathrm{kg}\end{array}$ & Not recorded & $\begin{array}{l}\text { Prolonged drug circulation } \\
\text { High tumor penetration } \\
\text { Anticancer effect with induced apoptosis }\end{array}$ & 95 \\
\hline \multicolumn{6}{|l|}{ Polymer } \\
\hline Doxorubicin & $\begin{array}{l}\text { Phase I } \\
\text { human }\end{array}$ & $\begin{array}{l}\text { Intravenous, } \\
508 \mathrm{mg} / \mathrm{m}^{2}\end{array}$ & $\begin{array}{l}\text { Dose-related vomiting and } \\
\text { nausea, loss appetite, anorexia, } \\
\text { mucositis, and oral ulceration } \\
\text { Parenthesis } \\
\text { Reversible hepatotoxicity } \\
\text { Alopecia, dermatological toxicity } \\
\text { No cardiac failure }\end{array}$ & $\begin{array}{l}\text { Tumors took up the drug } \\
\text { A minor response was seen on colorectal, } \\
\text { breast and NSCLC }\end{array}$ & 96 \\
\hline Cisplatin & Mice & Intravenous & Mild liver and cardiac toxicity & $\begin{array}{l}\text { Reduced tumor volume } \\
\text { Induced apoptosis } \\
\text { Prolonged drug circulation } \\
\text { Enhanced tumor infiltration }\end{array}$ & 97 \\
\hline $\begin{array}{l}\text { Gefitinib, cyclo- } \\
\text { sporin A }\end{array}$ & Mice & $\begin{array}{l}\text { Intravenous, } \\
10 \mathrm{mg} / \mathrm{kg} \text { each drug }\end{array}$ & No significant toxicity & $\begin{array}{l}\text { Reduce drug-resistant PC-9 cell xenografted } \\
\text { tumor growth } \\
\text { Increased bioavailability } \\
\text { Overcame multidrug resistance }\end{array}$ & 66 \\
\hline $\begin{array}{l}\text { siRNA targeting } \\
\text { STAT3 }\end{array}$ & Mice & $\begin{array}{l}\text { Intraperitoneal, } \\
0.5 \text { and } 1 \mathrm{mg} / \mathrm{kg}\end{array}$ & $\begin{array}{l}\text { Low inflammatory response } \\
\text { Not recorded }\end{array}$ & $\begin{array}{l}\text { Reduced alveolar tissue damage and STAT3 } \\
\text { express cells } \\
\text { Induced apoptosis via caspase activation } \\
\text { Suppressed tumor metastasis }\end{array}$ & 98 \\
\hline $\begin{array}{l}\text { 7-ethyl-10-hy- } \\
\text { droxy camptothe- } \\
\text { cin, a metabolite } \\
\text { of prodrug } \\
\text { irinotecan }\end{array}$ & Mice & $\begin{array}{l}\text { Surgical implanta- } \\
\text { tion of } 60 \mu \mathrm{g} / \text { film/ } \\
\text { mouse }\end{array}$ & $\begin{array}{l}\text { Mild inflammation at the sur- } \\
\text { gery site }\end{array}$ & $\begin{array}{l}\text { Freedom from local tumor growth was high } \\
\text { Formed distant tumors later } \\
\text { Prolonged slow rate of local drug release }\end{array}$ & 99 \\
\hline
\end{tabular}




\begin{tabular}{|c|c|c|c|c|c|}
\hline Etoposide & $\begin{array}{l}\text { Mice } \\
\text { model }\end{array}$ & $\begin{array}{l}\text { Intratumor, } 36 \mathrm{mg} / \\
\mathrm{kg}\end{array}$ & Not reported & $\begin{array}{l}\text { Reversed, prolonged and suppressed tumor } \\
\text { growth } \\
\text { Prolonged survival } \\
\text { Sustained drug release }\end{array}$ & 100 \\
\hline $\begin{array}{l}\text { Paclitaxel, cis- } \\
\text { platin }\end{array}$ & Mice & Intravenous & & $\begin{array}{l}\text { Reduced tumor volume than free drug } \\
\text { Showed lower toxicity than free drugs }\end{array}$ & 101 \\
\hline \multicolumn{6}{|c|}{ Peptide-based drug delivery } \\
\hline Doxorubicin & Mice & $\begin{array}{l}\text { Intravenous, 1mg/ } \\
\text { kg }\end{array}$ & No toxicity reported & $\begin{array}{l}\text { Enhanced radiation-induced therapeutic effect } \\
\text { (reduce tumor volume) } \\
\text { Increased necrosis and less functional blood } \\
\text { vessels } \\
\text { Increased drug accumulation in tumors } \\
\text { Selective drug delivery to radiated cells }\end{array}$ & 102 \\
\hline $\begin{array}{l}\text { Docetaxel and } \\
\text { DIM-C-pPhC6H5 } \\
\text { (DIM-P) }\end{array}$ & Mice & $\begin{array}{l}\text { Intravenous, } 5 \text { and } 2 \\
\mathrm{mg} / \mathrm{kg} \text {, respectively }\end{array}$ & No toxicity observed & $\begin{array}{l}\text { Reduced tumor number and size } \\
\text { Decreased metastatic lung tumors } \\
\text { Increased drug tumor penetration }\end{array}$ & 103 \\
\hline Doxorubicin & Mice & $\begin{array}{l}\text { Intravenous, } 7 \text { mg/ } \\
\text { kg }\end{array}$ & $\begin{array}{l}\text { A higher dose of the peptide } \\
\text { (>800 } \mathrm{mg} / \mathrm{kg} \text { ) ca used limb } \\
\text { necrosis. }\end{array}$ & $\begin{array}{l}\text { Reduced tumor size } \\
\text { Maintained body weight at a normal range }\end{array}$ & 78 \\
\hline \multicolumn{6}{|l|}{ Micelles } \\
\hline Cabazitaxel & Mice & $\begin{array}{l}\text { Intravenous, } 10 \\
\mathrm{mg} / \mathrm{kg}\end{array}$ & No toxic effect & $\begin{array}{l}\text { Reduced tumor size } \\
\text { Induced apoptosis } \\
\text { Prolonged survival }\end{array}$ & 104 \\
\hline $\begin{array}{l}\text { Paclitaxel and } \\
\text { survivin shRNA } \\
\text { which down-reg- } \\
\text { ulate survivin } \\
\text { gene expression } \\
\text { by RNA interfer- } \\
\text { ence }\end{array}$ & Mice & $\begin{array}{l}\text { Intravenous, } 10 \text { and } \\
2 \mathrm{mg} / \mathrm{kg} \text {, respec- } \\
\text { tively }\end{array}$ & No toxic effect & $\begin{array}{l}\text { PTX nanoparticles alone reduced tumor weight } \\
\text { Co-delivery of drug and gene-enhanced anti- } \\
\text { tumor effect } \\
\text { Increased drug tumor penetration }\end{array}$ & 105 \\
\hline Paclitaxel & Rat & $\begin{array}{l}\text { Intratracheal, } \\
2 \mathrm{mg} / \mathrm{kg}\end{array}$ & $\begin{array}{l}\text { No inflammatory signs in the } \\
\text { lung, Reduce systemic side } \\
\text { effects due to target delivery }\end{array}$ & $\begin{array}{l}\text { Increased localized and sustained drug release } \\
\text { in lung } \\
\text { Minimized systemic drug distribution }\end{array}$ & 106 \\
\hline Doxorubicin & Mice & $\begin{array}{l}\text { Intravenous, } \\
10 \mathrm{mg} / \mathrm{kg}\end{array}$ & $\begin{array}{l}\text { Concentration-dependent } \\
\text { toxicity; piloerection, adynamia, } \\
\text { tremor, and weight loss } \\
\text { At lower dose mild toxicity in } \\
\text { liver, lungs, kidney, and heart }\end{array}$ & Reduced metastasis tumor volume & 65 \\
\hline Acetylthevetin B & Mice & $\begin{array}{l}\text { Intravenous, } 1.5 \\
\mathrm{mg} / \mathrm{kg}\end{array}$ & Relatively weak cardiac toxicity & $\begin{array}{l}\text { High tumor-specific drug delivery } \\
\text { Inhibited tumor growth }\end{array}$ & 107 \\
\hline \multicolumn{6}{|l|}{ Dendrimers } \\
\hline Methotrexate & Rat & $\begin{array}{l}\text { Intravenous, } 20 \\
\mathrm{mg} / \mathrm{kg}\end{array}$ & No toxicity observed & $\begin{array}{l}\text { Low and prolonged systemic drug concentration } \\
\text { Lactoferrin conjugation enhanced drug accu- } \\
\text { mulation in lung tissues }\end{array}$ & 108 \\
\hline Doxorubicin & Mice & $\begin{array}{l}\text { Pharyngeal aspira- } \\
\text { tion or intravenous } \\
\text { delivery, } 1 \mathrm{mg} / \mathrm{kg}\end{array}$ & Low/no toxicity & $\begin{array}{l}\text { Reduced metastatic lung tumors } \\
\text { Reduced tumor size and mass compared to } \\
\text { free drug }\end{array}$ & 109 \\
\hline Doxorubicin & Rat & $\begin{array}{l}\text { Intratracheal instilla- } \\
\text { tion of } 3 \mathrm{mg} / \mathrm{kg}\end{array}$ & $\begin{array}{l}\text { Respiratory distress } \\
\text { Localized toxicity (necrosis) in } \\
60 \% \text { rats }\end{array}$ & $\begin{array}{l}\text { Rapid and complete absorption of the drug } \\
\text { Prolonged drug persistence in lung tissues } \\
\text { High drug tumor penetration } \\
95 \% \text { reduction in tumor burden compared } \\
\text { to intravenous injection of drug conjugated } \\
\text { dendrimer } \\
\text { Decreased lung metastasis }\end{array}$ & 70 \\
\hline
\end{tabular}

BCL2, B cell lymphoma 2; siRNA, small interferin RNA; TRAIL, tumor necrosis factor-related apoptosis inducing ligand; NSCLC, non- small cell lung cancer; STAT3, signal transducer and activator of transcription 3; DIM-P, 1,1-bis (3' indolyl)-1-(p-biphenyl) methane; VEGF, vascular endothelial growth factor; PTX, paclitaxel 


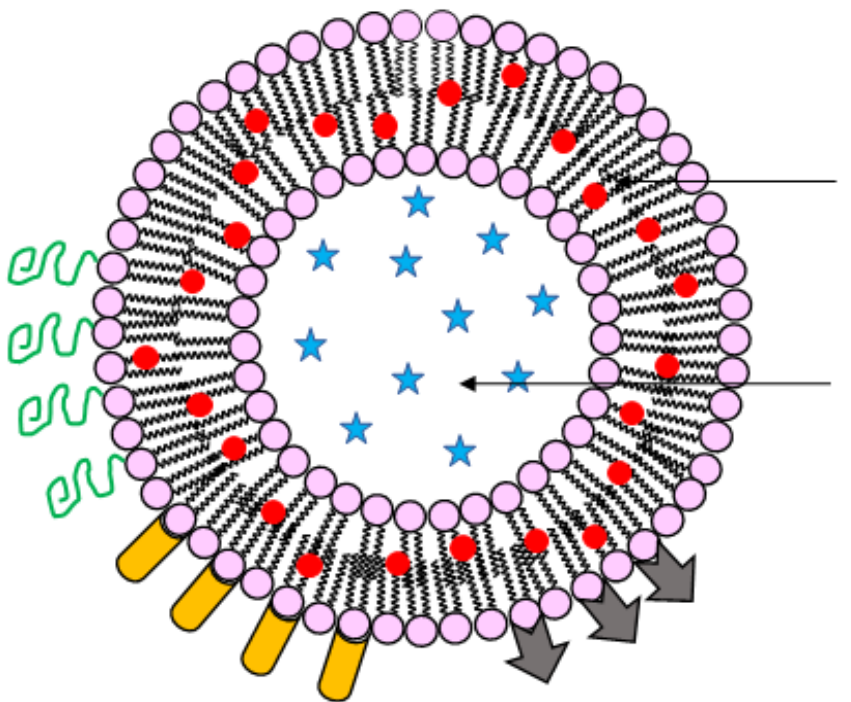

mимmm Lipophilic tail or polymer eS PEG
Hydrophilic head or polymer

Receptor binding
ligands
Lipophilic drugs

encapsulated in the lipophilic region

\author{
hydrophilic drugs entrapped \\ in the center hydrophilic \\ region (Doxorubicin)
}

Figure 3: An illustration of a unilamellar liposome nanoparticle. Hydrophilic drugs are trapped in the center core, whereas lipophilic drugs are encapsulated between the amphiphilic bilayer. Liposomes can be modified to enhance stealth properties that enhance circulation half-life, cell penetration ability, and targeted drug delivery by modifying their surface structure. PEGylation enhances the circulation time, while cell penetration peptides and receptor binding ligands facilitate cell permeability and targeted drug delivery, respectively.

\section{Micelles}

Micelles are nano-size structures with a self-assembled amphiphilic core-shell, that spontaneously form in aqueous environments by hydrophobic interactions. They are prepared by dissolving individual polymeric chains in aqueous solution above a threshold concentration (critical micelle concentration; the concentration of surfactant in water which initiates the formation of micelles) and solution temperature (critical micelle temperature; the lowest temperature, at which surfactants form micelles in water) ${ }^{62,63}$. Most micelles are made up of amphiphilic polymers such as polyethylene glycol (PEG) and polyethylene oxide (PEO), which are FDA-approved excipients ${ }^{64}$. The selection of polymeric materials in the manufacturing of micelles is important, as the polymers determine micelle size and shape, stability and drug retention. Incorporation of hydrogenated soy phosphatidylcholine changes the shape of PEG-PE micelles and reduces drug retention within the nanoparticle by decreasing electrostatic interactions between the cargo (doxorubicin) and PEG-phosphatidylethanolamine (PE) ${ }^{65}$. Because of lower molecular mass and easy renal clearance of polymeric residuals after micelle degradation, unimeric micelles are more suitable for drug delivery than di-block (hydrophilic-hydrophobic) or triblock (hydrophilichydrophobic-hydrophilic) particles (Fig 4). Micelles composed of a hydrophobic core that facilitates the loading of hydrophobic drugs, such as paclitaxel and tamoxifen, and a hydrophilic shell, which acts as a barrier for particle aggregation protein binding and opsonization, degrade in the systemic circulation prior to reaching the target tissue $^{62}$. Two different anticancer drugs can co-encapsulate together in micelles to enhance the drug loading efficiency and synergize the anticancer effect ${ }^{66}$. For example, coencapsulation of paclitaxel with $\beta$-lapachone (LPC), a novel cytotoxic drug activated by quinone oxidoreductase 1 (NQ01), in poly(ethylene glycol)-b-poly(D, L-lactic acid) inhibits the crystallization of LPC, enhances LPC drug loading efficiency and shows synergistic cytotoxicity against A549 non-small cell lung cancer cells ${ }^{67}$.

\section{Dendrimers}

Dendrimers (also known as dendritic polymers) are nanoparticles that resemble a series of tree-like branches surrounding a central core. Figure 5 illustrates the basic structure of a dendrimer. The multi-factional surface shell and hyper-branching tree-like interior with cavities facilitates conjugation or encapsulation of drug molecules. In addition, the ability to modify the active terminal surface by acylation or PEGylation improves dendrimer bioavailability, while conjugating target peptides or receptor proteins with dendrimers enhances targeted 
Lipophilic drugs encapsulate in the lipophilic region (Paclitaxel, tamoxifen)

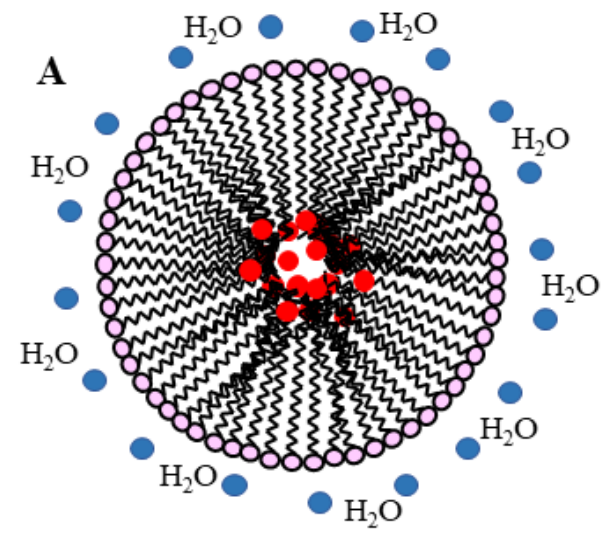

мимимn Lipophilic tail or polymer
Hydrophilic head or polymer

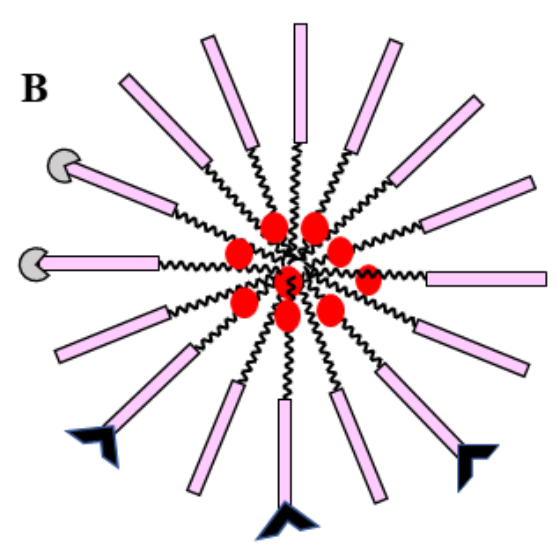

Receptor binding $\hookrightarrow$ Antibody ligands

Figure 4: Schematic representation of micelle formation by amphiphilic surfactants (A) or copolymers (B). In aqueous systems, micelles are formed spontaneously by orienting the hydrophobic tail or polymer away from water molecules, while the hydrophilic head or polymer interact with polar water molecules, resulting in a spherical molecule. Conjugation of receptor binding ligands or antibody targets on the micelle shell enhances targeted drug delivery. Alternatively, modification by PEGylation enhances the micelle longevity in vivo.

\section{Molecules can conjugate with terminal surface of the branches}

\section{Molecules can encapsulate within the branches}

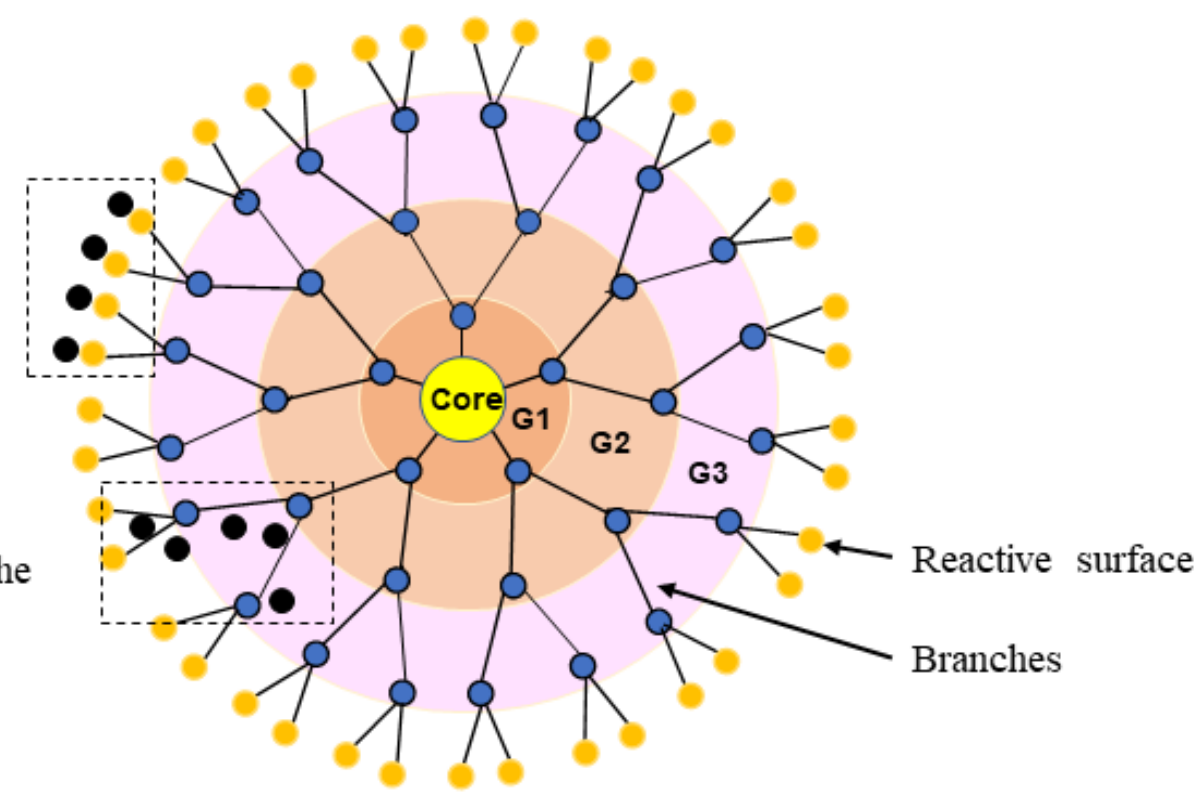

Figure 5: Dendrimer architecture. Dendritic nanoparticles are composed of three different sections; core, at the center, interior, branched cell amplification region, and surface, terminal reactive groups. Branches are attached to the core as shells and nomenclature as generations (G1, G2, G3, etc.) that build by repeating a series of chemical reactions. The spherical branching structure or the number of layers of a dendrimer can expand up to the desired size (macromolecular structure).

drug delivery ${ }^{68}$. Molecular weight and composition determine the absorption efficiency and retention of dendrimers in the lungs. For example, the inhalation of higher molecular weight $(78 \mathrm{kDa})$ dendrimers results in reduced absorption rate and enhanced drug retention in the lung tissues compared to small molecular weight $(<22 \mathrm{kDa})$ dendrimers ${ }^{69}$. In addition, respiratory delivery of doxorubicin-conjugated PEGylated dendrimers leads to prolonged drug residence in lung tissues and effective lung tumor burden reduction in rats ${ }^{70}$. Drug delivery can be enhanced by decorating dendrimers with targeting peptides, as is the case with generation 4 (G4) dendrimers coupled to non-small cell lung cancer targeting peptides (sequence RCPLSHSLICY) ${ }^{71}$. Anti-epidermal growth 

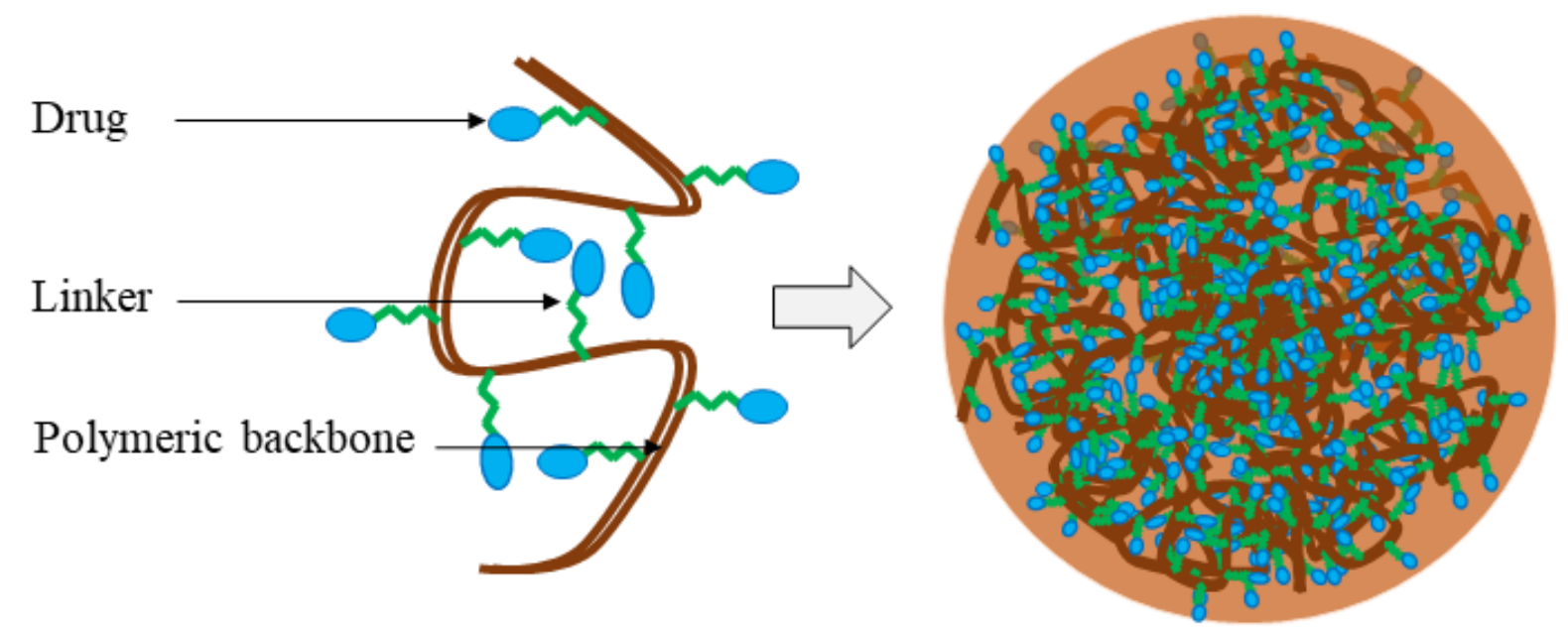

Figure 6: Schematic diagram of a drug-conjugated polymeric nanoparticle. The therapeutic agent is attached to the soluble polymeric backbone by a biodegradable or cleavable linker or spacer.

factor receptor antibody-conjugated poly(amidoamine) dendrimers have a stable and higher binding affinity in vitro and in vivo, in cyclin E-overexpressing transgenic mice $^{68}$.

\section{Polymer-based nanoparticles}

Polymeric nanoparticles are colloidal systems, in which the therapeutic agents are either embedded within the polymeric matrix or adsorbed to the surface of the nanoparticles (Figure 6). There are two types of polymerbased nanoparticles; nanospheres, in which the drug is uniformly distributed, and nanocapsules, in which the drug is entrapped into a cavity surrounded by a polymer layer ${ }^{57,72}$. However, to be an effective drug delivery system, the selected polymer should be 1) biocompatible, 2) nonimmunogenic, 3) easy to synthesize and inexpensive, 4) water-soluble, and 5) biodegradable in vivo to minimize possible toxicity resulting from accumulated nonmetabolized polymeric particles ${ }^{72}$. In some cases, a linker is inserted between the polymer and the therapeutic agent to facilitate stability and prevent liberation into the circulation after cellular delivery. For example, $90 \%$ of lactoferrin-chondroitin sulfate nanoparticles (192 nm) containing doxorubicin and ellagic acid deposit in deep lung tissues, thereby increasing the therapeutic index of the drug ${ }^{73}$. Polymers used in drug delivery systems can be either natural or synthetic. Chitosan, gelatin, cellulose, and alginate are natural, biodegradable polymers. Polylactic acid, poly(alkyl cyanoacrylates), polyanhydrides and poly(lactide-co-glycolide) (PLGA) are examples of synthetic biodegradable polymers used in nanoparticle preparation $^{57}$.

\section{Peptide-based nanoparticles}

Small peptides such as growth factors and neurotransmitters are involved in many physiological functions in the human body. These naturally occurring peptide molecules comprising <30 amino acids are not often used clinically owing to their poor chemical and physical stability and short half-life in systemic circulation due to glomerular filtration and serum protein degradation $^{74,75}$. However, small peptides have many advantageous properties as therapeutic agents since they can easily penetrate cells and release drugs in response to tissue $\mathrm{pH}$. For example, peptide conjugated liposomes have effectively internalized into mitochondria by reversing its surface charge (negative to positive) in the tumor extracellular environment $(\mathrm{pH} \sim 6.8)^{60}$. Hence, peptidebased nanoparticles have gained attention as gene and drug transporters to the targeted tissues ${ }^{74}$. For instance, intravenous administration of cisplatin and methotrexate, separately mixed with K16ApoE (Mayo Proteomic Core Facility) transporter peptide, increased the drug penetration and brain-uptake of both drugs compared to free drug injections ${ }^{76}$. Similarly, peptide, RLWMRWYSPRTRAYGC has selective cell-penetrating ability and targets drug delivery in A549 xenografted lung cancer cells ${ }^{77}$. Enzymatic degradation can be minimized and the half-life of peptides in blood circulation improved by modifying the physical and chemical structure of peptide molecules. Previously used strategies include structural modification of peptides by conjugating with d albumin, albumin-binding antibody or cell-penetrating peptides, PEGylation to enhance circulation half-life, and binding with nuclear localizing sequences to enhance the targeted drug delivery ${ }^{75,78}$. Since the pulmonary mucosal surface is rich in anti-protease enzymes, it is naturally permeable to small molecule peptides and proteins after their inhalation. Therefore, pulmonary delivery of peptide-based nanoparticles may result in faster absorption and increased local, as well as 
Table 4. Materials used in nanoparticle preparation

\begin{tabular}{|c|c|}
\hline Material & Property \\
\hline \multicolumn{2}{|l|}{ Liposome and micelles } \\
\hline Cholesterol & $\begin{array}{l}\text { Lipophilic, biocompatible, yellow crystals } \\
\text { Stable over a wide range of temperatures }\end{array}$ \\
\hline $\begin{array}{l}\text { Phospholipids } \\
\text { Phosphatidylcholine } \\
\text { Phosphatidylglycerol } \\
\text { Phosphatidylethanolamine }\end{array}$ & $\begin{array}{l}\text { Amphiphilic molecules, having a polar head and a lipophilic tail } \\
\text { Neutral charged } \\
\text { Negatively charged } \\
\text { Neutral charge }\end{array}$ \\
\hline Soybean phosphatidylserine & Natural phospholipids \\
\hline \multicolumn{2}{|l|}{ Polymers in nanoparticle preparation } \\
\hline $\begin{array}{l}\text { Poly(ethylene glycol) } \\
\text { Poly(ethylene oxide) }\end{array}$ & $\begin{array}{l}\text { Highly water soluble, non-toxic } \\
\text { Reduce immunogenicity } \\
\text { Have antifouling properties } \\
\text { Prevent the opsonin and phagocytosis }\end{array}$ \\
\hline Poly(N-[2-hydroxypropyl]-methacrylamide) & $\begin{array}{l}\text { Biocompatible synthetic } \\
\text { Hydrophilic, non-toxic even at higher levels } \\
\text { Prolong drug retention } \\
\text { Nonimmunogenic }\end{array}$ \\
\hline Dextran & $\begin{array}{l}\text { Biodegradable polysaccharide } \\
\text { Prolong drug circulation }\end{array}$ \\
\hline Chitosan & $\begin{array}{l}\text { Biodegradable co-polymer } \\
\text { Mw } 50,000-2 \text { million Da }\end{array}$ \\
\hline Polyethylenimine & Cationic polymer \\
\hline Poly(lactide-co-glycolide) & $\begin{array}{l}\text { Biodegradable and biocompatible } \\
\text { Encapsulate lipophilic drugs }\end{array}$ \\
\hline Gelatine & $\begin{array}{l}\text { Biocompatible and biodegradable } \\
\text { Gels at } 35-40 \text { ○C }\end{array}$ \\
\hline \multicolumn{2}{|l|}{ Peptides } \\
\hline Elastin-like polypeptide & $\begin{array}{l}\text { Thermal response to hyperthermic conditions } \\
\text { Passive acumination in tumor cells }\end{array}$ \\
\hline Syn-B1 & Higher cell permeability rate \\
\hline YSA peptide & Target ephrin type-A receptor 2 on cancer cells \\
\hline GE11 & Target epidermal growth factor receptor \\
\hline HVGGSSV peptide & Target irradiated tumors \\
\hline
\end{tabular}

systemic, bioavailability in comparison to subcutaneous or intravenous injections. Popular materials used in peptidebased nanoparticle preparation are listed in Table 4.

\section{Aerosolized anticancer treatments for lung cancer}

Even though systemic drug delivery via nanocarriers is more efficient than conventional intravenous drug administration for lung cancer, direct anticancer drug delivery by inhalation (see Table 5 ) has several additional advantages. Aerosols provide direct delivery of anticancer drugs to the target cancer cells and thus increased therapeutic efficacy at lower drug concentrations. In this regard, direct topical application of paclitaxel nanoparticles enhances treatment efficacy at a significantly lower drug concentration (1 $\mathrm{mg} / \mathrm{kg})$ compared to intravenous administration of paclitaxel nanoparticles $(2$ $\mathrm{mg} / \mathrm{kg})^{79}$. Moreover, direct delivery avoids adverse side effects common in systemic anticancer treatments. For example, the administration of aerosolized doxorubicinnanoparticles through dry powder aerosolizers has reduced cardiotoxicity, prolonged survival (up to 140 days vs. $<50$ days), and suppressed the lung metastasis in mice compared to the intravenous delivery of the free drug as well as doxorubicin nanoparticles ${ }^{80}$. The use of ligands for specific receptors expressed by tumor cells enhances targeted drug delivery and results in minimal side effects. For instance, inhalation of doxorubicincontaining nanoparticles decorated with tumor necrosis factor-related apoptosis-inducing ligand (TRAIL) results in a synergistic inhibition of tumor metastasis in mice when compared to naked doxorubicin-containing nanoparticles. TRAIL specifically binds to death receptors 4 and 5 expressed on metastatic lung cancer cells in mice, thereby enhancing targeted drug delivery and cancer cell apoptosis ${ }^{81,82}$. Additionally, incorporation of the common lung chemotherapeutics, doxorubicin, and cisplatin, into a gelatin nano aerosol complexed with epidermal growth 
Table 5. Aerosolized anticancer nanoparticles to treat lung cancer.

\begin{tabular}{|c|c|c|c|c|c|}
\hline Drug & Device and test model & Nanoproduct & Size & Observation & Reference \\
\hline $\begin{array}{l}\text { Doxorubicin and } \\
\text { ellagic acid }\end{array}$ & $\begin{array}{l}\text { Dry powder insufflator } \\
\text { BALB/c mice }\end{array}$ & $\begin{array}{l}\text { Lactoferrin-chon- } \\
\text { droitin }\end{array}$ & $192 \mathrm{~nm}$ & $\begin{array}{l}\text { Reduces the size and number of lung tumors } \\
\text { Induces caspase } 3 \text { activation (2-fold higher than free drug } \\
\text { inhalation) and suppresses the expression of Ki-67 (3-fold } \\
\text { from negative control) and VEGF-1 (2-fold reduction) }\end{array}$ & 73 \\
\hline Doxorubicin & $\begin{array}{l}\text { Nebulizer } \\
\text { BALB/c mice }\end{array}$ & bEGF/gelatin & $\sim 120 \mathrm{~nm}$ & $\begin{array}{l}\text { Reduces tumor volume by } 90 \% \\
\text { Induces caspase } 3 \text { activations, resulting in apoptosis } \\
\text { Suppresses metastasis by lowering MMP9 level } \\
100 \% \text { survival rate } \\
\text { Enhances drug availability in tumor cells } \\
\text { No induction of inflammation and immune response }\end{array}$ & 83 \\
\hline Doxorubicin & $\begin{array}{l}\text { Dry powder insufflator } \\
\text { C57BL/6 mice }\end{array}$ & $\begin{array}{l}\text { PLGA porous } \\
\text { nanoparticles }\end{array}$ & $14 \mu \mathrm{m}$ & $\begin{array}{l}\text { Drug deposits in center of the lung and gradually } \\
\text { disperses to the periphery over time } \\
\text { Reduces metastasis lung tumors by } 50 \% \\
\text { No toxic conditions }\end{array}$ & 110 \\
\hline $\begin{array}{l}\text { Doxorubicin + } \\
\text { TRAIL }\end{array}$ & $\begin{array}{l}\text { Dry powder insufflator } \\
\text { BALB/c nu/nu mice }\end{array}$ & TRAIL/PLGA & $11.5 \mu \mathrm{m}$ & $\begin{array}{l}\text { Synergistic reduction of metastasis by } 70 \% \text { vs. } \\
\text { nontreated group and } 50 \% \text { vs. doxorubicin-liposome } \\
\text { inhalation } \\
\text { Induces apoptosis } \\
\text { Reduces the effective drug dosage and prolongs drug } \\
\text { release }\end{array}$ & 81 \\
\hline Doxorubicin & $\begin{array}{l}\text { Dry powder insufflator } \\
\text { BALB/c mice }\end{array}$ & $\begin{array}{l}\text { Polybutyl cyanoac- } \\
\text { rylate }\end{array}$ & $145 \mathrm{~nm}$ & $\begin{array}{l}\text { Prolongs survival compared to free drug inhalation } \\
\text { and systemic delivery } \\
\text { Reduces metastasis } \\
\text { Less cardiotoxicity } \\
\text { Sustained drug release }\end{array}$ & 80 \\
\hline $\begin{array}{l}\text { Doxorubicin + } \\
\text { TRAIL }\end{array}$ & $\begin{array}{l}\text { Micro spray aerosolizer } \\
\text { BALb/c nu/nu mice }\end{array}$ & Serum albumin & $\sim 340 \mathrm{~nm}$ & $\begin{array}{l}\text { Synergistic reduction of lung metastasis }(40 \%) \text { and } \\
\text { induces apoptosis compared to doxorubicin nanopar- } \\
\text { ticle inhalation }\end{array}$ & 82 \\
\hline $\begin{array}{l}\text { Doxorubicin, } \\
\text { cisplatin }\end{array}$ & $\begin{array}{l}\text { Micro sprayer } \\
\text { C57BL/6 mice }\end{array}$ & mPEG-OEI-PLG & $\begin{array}{c}40-65 \\
\mathrm{~nm}\end{array}$ & $\begin{array}{l}\text { Increases accumulation in tumor tissues compared to } \\
\text { normal tissues } \\
\text { Enhances cellular uptake } \\
\text { Suppresses tumor metastasis } \\
\text { No sign of toxicity }\end{array}$ & 111 \\
\hline $\begin{array}{l}\text { Doxorubicin/pacl- } \\
\text { itaxel }(2: 1)\end{array}$ & $\begin{array}{l}\text { Dry powder insufflator } \\
\text { C57BL/6 mice }\end{array}$ & PLGA & $11.5 \mu \mathrm{m}$ & $\begin{array}{l}\text { Reduces lung tumor lesions compared to a non- } \\
\text { treated and individual drug-containing nanoparticle } \\
\text { inhalation } \\
\text { Shows healthy alveoli }\end{array}$ & 112 \\
\hline Paclitaxel & $\begin{array}{l}\text { Microspray aerosolizer } \\
\text { BALB/c mice }\end{array}$ & F-PEG-HMD & $50 \mathrm{~nm}$ & $\begin{array}{l}\text { Reaches tumor cells } \\
\text { No sign of toxicity or inflammation in lung tissues }\end{array}$ & 113 \\
\hline Paclitaxel & Nebulizer B6D2F1 mice & $\begin{array}{l}\text { Solid lipid } \\
\text { nanoparticles }\end{array}$ & $92 \mathrm{~nm}$ & $\begin{array}{l}\text { Suppresses tumor growth by } 75 \% \text { and completely } \\
\text { suppresses metastasis compared to intravenous } \\
\text { administration } \\
\text { Fewer side effects }\end{array}$ & 79 \\
\hline Paclitaxel & $\begin{array}{l}\text { Micro sprayer CD1 and } \\
\text { BALB/c mice }\end{array}$ & $\begin{array}{l}\text { Lipid nanoparticles } \\
\text { coated with F-PEG- } \\
\text { HTCC }\end{array}$ & $250 \mathrm{~nm}$ & $\begin{array}{l}\text { Prolongs local drug availability } \\
\text { Reduces systemic drug penetration } \\
\text { Induces antiproliferative properties of the free drug }\end{array}$ & 114 \\
\hline $\begin{array}{l}\text { Doxorubicin/cis- } \\
\text { platin }\end{array}$ & $\begin{array}{l}\text { Nebulizer NCR nude } \\
\text { mice }\end{array}$ & MSN & $180 \mathrm{~nm}$ & $\begin{array}{l}\text { Increases lung retention (73\%) compared to intrave- } \\
\text { nous delivery (5\%) } \\
\text { Reduces systemic circulation and accumulation in } \\
\text { other organs, liver (17\%) kidney (9\%) }\end{array}$ & 115 \\
\hline Cisplatin & Nebulizer SCID mice & bEGF/gelatin & $230 \mathrm{~nm}$ & $\begin{array}{l}\text { Prolongs drug retention in the lungs ( } 6 \mathrm{ppb}, 48 \mathrm{~h}) \text { vs. } \\
(0.8 \mathrm{ppb}, 48 \mathrm{~h}) \text { in free drug inhalation } \\
\text { Shows targeted drug delivery and less nephrotoxicity }\end{array}$ & 84 \\
\hline Gemcitabine & Nebulizer human & Aerosol & $\begin{array}{c}\text { Not } \\
\text { mention }\end{array}$ & $\begin{array}{l}42 \% \text { drug dose deposit in the lungs } \\
\text { Minimal systemic cytotoxicity and dose liming toxicity } \\
\text { at } 4 \mathrm{mg} / \mathrm{kg} \\
\text { Individual variability in therapeutic effect } \\
\text { Lower plasma drug concentration }\end{array}$ & 85 \\
\hline
\end{tabular}




\begin{tabular}{|c|c|c|c|c|c|}
\hline Celecoxib & $\begin{array}{l}\text { Dry powder insufflator } \\
\text { A/J mice }\end{array}$ & Porous PLGA & $10.5 \mu \mathrm{m}$ & $\begin{array}{l}\text { Superior drug delivery by porous NP ( } 570 \mathrm{ng} / \mathrm{g} \text { lung } \\
\text { tissue/ mg dose) compared to nonporous NP (118) } \\
\text { and free drug (11) } \\
50 \text {-fold higher drug retention vs. free drug Inhibit } \\
\text { tumor formation by } 70 \% \\
\text { Reduces tumor multiplicity } \\
\text { Decreases VEGF by } 35 \% \\
\text { Enhances drug retention in lungs and blood up to } 21 \\
\text { days } \\
\text { Not toxic to lung tissues }\end{array}$ & 116 \\
\hline $\begin{array}{l}\text { Rapamycin and } \\
\text { berberine }\end{array}$ & $\begin{array}{l}\text { Dry powder insufflator } \\
\text { Albino mice }\end{array}$ & Phospholipids & $\begin{array}{l}200-250 \\
\mathrm{~nm}\end{array}$ & $\begin{array}{l}\text { Reduces tumor growth } 93 \% \text { to that of positive control } \\
\text { and } 19 \% \text { from free drug inhalation } \\
\text { Induces caspase- } 3 \text { activation by } 3 \text {-fold and inhibits } \\
\text { VEGF-1 expression by } 4 \text {-fold relative to the positive } \\
\text { control. }\end{array}$ & 117 \\
\hline
\end{tabular}

bEGF, basic epidermal growth factor; MMP9, matrix metallopeptidase 9; PLGA, poly(lactide-co-glicolide); TRAIL, tumor necrosis factor-related apoptosis inducing ligand; F-PEG-HMD, folate-polyethylene glycol-hydrophobically-modified dextran; MSN, mesoporous silica nanoparticles; NP, nanoparticles; VEGF, vascular endothelial growth factor; F-PEG-HTCC, Folate-Poly(ethylene glycol)-N-[(2-hydroxy-3-trimethylammonium) propyl] chitosan; mPEG-OEI-PLG; , ethoxy poly(ethylene glycol)-poly(ethylenimine)-poly(L-glutamate)

factor ligand demonstrates increased localized drug concentration ( $4 \mu \mathrm{g} / \mathrm{g}$ lung tissue $24 \mathrm{~h}$ postadministration), lower systemic concentrations and enhanced therapeutic effect in a mouse model of metastatic lung cancer ${ }^{83,84}$. In contrast, inhalation of an anticancer drug, gemcitabine, results in pulmonary toxicities such as bronchospasm in lung cancer patients, but no systemic toxicity, such as neurotoxicity, nephrotoxicity, and hematologic toxicity ${ }^{85}$. In addition, aerosolized nanoparticles containing doxorubicin and ellagic acid show promising antitumor efficacy in BALB/c mice compared to inhalation of the combined free drugs and intravenous injection of the drug-nano complex $^{73}$. Importantly, aerosol generators do not need invasive needle-based delivery and the patients can selfadminister the anticancer drug. However, while respiratory anticancer drug delivery shows great potential, drug toxicities are still possible. Therefore, further research and optimization of nanoparticle delivery of anticancer drugs via the respiratory route are required.

\section{Conclusions and future directions}

Inhalation of chemotherapeutic nanoparticles assures a more effective method of intact drug delivery to the lung in comparison to conventional intravenous drug delivery, as well as eliminating or minimizing any drug-related toxicity to normal tissues (Table 5). The opportunity for drug delivery only to targeted tissues by nanoparticles through PEGylation, peptide, or receptor ligand conjugation provides a mechanism to produce an effective concentration of drug locally with reduced doses having less cytotoxicity compared to topical application of the free drug. Many studies have confirmed that cytotoxicity is lower when chemotherapeutics are encapsulated in nanocarriers versus delivering them as free drug solutions. Further, needleless drug administration would enhance the patient's psychological status and willingness to attend a regular treatment program, especially in relation to painful administration of chemotherapeutics. Nanoparticle size, mass median aerodynamic diameter, chemical structure, drug encapsulation efficiency, bioavailability, and biodegradability, as well as the type of delivery device, should be taken into consideration when designing an inhalable anticancer drug carrier for lung cancer. For example, the mass median aerodynamic diameter of nanoparticles affects the nanoparticle distribution, deposition, and mucociliary and/or phagocytotic clearance of drugs in the alveolar epithelium. Furthermore, PEGylation enhances the retention and bioavailability of drug carriers on lung epithelium for prolonged localized drug delivery.

Even though lung cancer arises on lung epithelium that is accessible to inhalable aerosol drugs, the center of origin can be anywhere in the lung. Usually, small cell lung cancer arises centrally on bronchus epithelium, while non-small cell lung cancer, such as adenocarcinoma and large cell carcinoma, arises on peripheral bronchioles and alveolar epithelium. Therefore, the drug carriers should localize to central airways for treating small cell lung cancer, while for adenocarcinoma carrier localization should be peripheral. Aerosol nanoparticles at $5-10 \mu \mathrm{m}$ geometric range could be effective for treating small cell lung cancer as they deposit by impaction on central airway epithelium. However, anticancer drugs need to reach deep into lung tissues to treat adenocarcinoma. Gravitational sedimentation and diffusion of small particles (0.1 -3 $\mu \mathrm{m}$ size) can effectively deposit these nanoparticles in peripheral lung tissues and could be effective in treating adenocarcinoma.

The stage of lung cancer (localized or metastasis) varies from individual to individual, and hence the drugcontaining nanocarrier should be designed to address both localized and systemic drug delivery. Drugs need to 
reside within lung tissues for sustained drug release to treat localized lung cancer, while systemic absorption of the drug is necessary for treating stage IV lung tumors, which have already spread to the distal lymph nodes or other organs, such as liver, bones and brain. Localized and systemic drug delivery via the pulmonary route at the same time is challenging because of the aerodynamic nature of the nanoparticles. The use of multilamellar liposomes is a good approach for localized anticancer drug delivery, whereas the use of dendrimers is a better option for systemic anticancer drug delivery owing to their diversity in particle size.

Generally, lung cancer is diagnosed at a later stage of the disease. Trouble with breathing and taking short, frequent breaths are common among advanced stage lung cancer patients. Even for the early stage lung cancer patients, difficulty in breathing can be common after a lobectomy. The delivery of an effective drug dose, especially to peripheral lung tissues, can be quite challenging as the total lung capacity and tidal volume is low in such patients. This may directly affect the efficacy of inhalers as the breathing velocity affects pulmonary distribution and deposition of aerosolized drug particles or nanocarriers. The introduction of a spacer and a power source to generate and deliver nano size molecules could help patients to effectively inhale drugs deep into lung tissues.

The topical application of chemotherapeutic agents incorporated into nanoparticles is promising compared to topical application of free drugs or intravenous injection of drug-containing nanocarriers; however, there are limitations that need to be addressed by additional research. Liposomes and lipid-based nanoparticles are less stable, easily undergo oxidative degradation, and agglomerate, resulting in poor drug effectiveness. Since most lung cancers are diagnosed at an advanced stage, it is necessary to develop nanoparticles and a delivery strategy to reach both central and peripheral lung tissues, as well as systemic circulation, to facilitate drug access to local and distal metastatic tumor nodules. Most lung cancer patients have a smoking history or long-term exposure to other occupational or environmental toxicants that affect the structure of lung epithelium. These patients also have a frequent cough and difficulty in breathing due to cancer or poor physical condition, age, or asthma. These patient-related conditions directly affect the breathing rate, vital lung capacity, and inhaler efficiency, which generate irregularities in drug distribution, deposition, and absorption in lung tissues. Thus, patient conditions should be taken into consideration when developing novel aerosol delivery devices and designing treatment plans. Consequently, research should focus on the search for effective nanocarriers with higher stability and the capacity for deagglomeration, as well as enhanced penetration into solid tumors. Modification of the physical (mass median diameter and porosity) and chemical (amphiphilic particles, add target ligands, and stable polymers) properties of nanoparticles could be useful to maintain stability and prevent agglomeration during storage. It is also possible to incorporate a drug into multiple nanoparticles, such as liposomes, dendrimers, micelles to achieve a synergistic enhancing effect on local and systemic delivery. A combination of topical and systemic drug-nanoparticle delivery should be considered to deliver an effective drug dose for patients who have breathing difficulties.

In summary, inhalation of anticancer drugs is an attractive treatment strategy, owing to its noninvasive characteristics and capacity for patient-driven delivery. As the drug delivery mechanism can have a large influence on drug efficacy, 1) locality of lung cancer, 2) stage of lung cancer and 3) the respiratory rate and volume of individuals are important to consider when designing a delivery vehicle for anticancer drugs.

\section{Acknowledgments}

The authors acknowledge the support of the Cancer Research Training Program of the Beatrice Hunter Cancer Research Institute, with funds provided by the Sauder'sMatthey Cancer Prevention Foundation.

\section{References}

1. Bray F, Ferlay J, Soerjomataram I, et al. Global cancer statistics 2018: GLOBOCAN estimates of incidence and mortality worldwide for 36 cancers in 185 countries. CA Cancer J Clin. 2018; 68: 394-424.

2. Zhan J, Zhu X, Guo Y, et al. Opposite role of Kindlin-1 and Kindlin-2 in lung cancers. PLoS One. 2012; 7: e50313.

3. Field RW, Withers BL. Occupational and environmental causes of lung cancer. Clin Chest Med. 2012; 33: 681-703.

4. Couraud S, Zalcman G, Milleron B, et al. Lung cancer in never smokers - A review. Eur J Cancer. 2012; 48: 1299-1311.

5. Brambilla E. in Pathology and Genetics of Tumours of the Lung, Pleura, Thymus and Heart (eds. Travis, W. D., Brambilla, E., MüllerHermelink, H. K. \& Harris, C. C.) 45-51 (IARCPress International Agency for Research on Cancer (IARC), 2004).

6. Hammar SP. in Pathology and Genetics of Tumours of the Lung, Pleura, Thymus and Heart (eds. Travis, W. D., Brambilla, E., Müller-Hermelink, H. K. \& Harris, C. C.) 31-34 (IARC Press, International Agency for Research on Cancer, 2004).

7. Colby TV. in Pathology and Genetics of Tumours of the Lung, Pleura, Thymus and Heart (eds. Travis, W. D., Brambilla, E., Müller-Hermelink, H. K. \& Harris, C. C.) 35-44 (IARC Press, International Agency for Research on Cancer, 2004).

8. Neal JW, Gubens MA, Wakelee HA. Current management of small cell lung cancer. Clin Chest Med. 2011; 32: 853-863.

9. Onugha OI, Lee JM. in Lung Cancer: Treatment and Research (ed Reckamp, K. L.) 77-105 (Springer International Publishing, 2016). doi:10.1007/978-1-61779-542-8

10. Sampath S. in Lung Cancer: Treatment and Research (ed. Reckamp, K. L.) 105-118 (Springer International Publishing, 2016). doi:DOI 10.1007/978-3-319-40389-2_6 
11. Dietrich MF, Gerber DE. in Lung Cancer: Treatment and Research (ed. Reckamp, K. L.) 119-150 (Springer International Publishing, 2016). doi:DOI 10.1007/978-3-319-40389-2_6

12. Macdonald V. Chemotherapy: Managing side effects and safe handling. CVJ. 2009; 50: 665-668.

13. Greenlee H, Shaw J, Lau YI, et al. Lack of effect of coenzyme Q10 on doxorubicin cytotoxicity in breast cancer cell cultures. Integr Cancer Ther. 2012; 11: 243-50.

14. Miller RP, Tadagavadi RK, Ramesh G, et al. Mechanisms of cisplatin nephrotoxicity. Toxins (Basel). 2010; 2: 2490-2518.

15. Suresh R, Ali S, Ahmad A, et al. in Lung Cancer and Personalized Medicine: Novel Therapies and Clinical Management, Advances in Experimental Medicine and Biology (eds. Ahmad, A. \& Gadgeel, S. M.) 890: 57-75. (Springer International Publishing, 2016).

16. Uramoto H, Tanaka F. Recurrence after surgery in patients with NSCLC. Transl Lung Cancer Res. 2014; 3: 242-249.

17. Shi Y, Hu Y, Hu X, et al. Cisplatin combined with irinotecan or etoposide for untreated extensive-stage small cell lung cancer: A multicenter randomized controlled clinical trial. Thorac. Cancer. 2015; 6: 785791.

18. Nuijten M, Heigener DF, Bischoff $H G$, et al. Effectiveness of bevacizumab- and pemetrexed-cisplatin treatment for patients with advanced non-squamous non-small cell lung cancer. Lung Cancer. 2010; 69: 4-10.

19. Koolen SL, Beijnen JH, Schellens JH. Intravenous-to-oral switch in anticancer chemotherapy: A focus on docetaxel and paclitaxel. Clin Pharmacol Ther. 2009; 87: 126-129.

20. Paranjpe M, Muller-Goymann CC. Nanoparticle-mediated pulmonary drug delivery: A review. Int J Mol Sci. 2014; 15: 5852-5873.

21. Smola M, Vandamme T, Sokolowski A. Nanocarriers as pulmonary drug delivery systems to treat and to diagnose respiratory and nonrespiratory diseases. Int J Nanomedicine. 2008; 3: 1-19.

22. Jeannot V, Gauche C, Mazzaferro S, et al. Anti-tumor efficacy of hyaluronan-based nanoparticles for the co-delivery of drugs in lung cancer. J Control Release. 2018; 275: 117-128.

23. Amreddy N, Babu A, Panneerselvam J, et al. Chemo-biologic combinatorial drug delivery using folate receptor-targeted dendrimer nanoparticles for lung cancer treatment. Nanomedicine Nanotechnology Biol Med. 2018; 14: 373-384.

24. Liu C, Shaurova T, Shoemaker S, et al. Tumor-targeted nanoparticles deliver a vitamin D-based drug payload for the treatment of EGFR tyrosine kinase inhibitor-resistant lung cancer. Mol Pharm. 2018; 15 3216-3226.

25. Haughney J, Price D, Barnes NC, et al. Choosing inhaler devices for people with asthma: Current knowledge and outstanding research needs. Respir Med. CME. 2010; 3: 125-131.

26. Loira-Pastoriza C, Todoroff J, Vanbever R. Delivery strategies for sustained drug release in the lungs. Adv Drug Deliv Rev. 2014; 75: 81-91.

27. Olsson B. in Controlled Pulmonary Drug Delivery, Advances in Delivery Science and Technology (eds. Smyth HDC, Hickey AJ.) 21-50 (AstraZeneca R \& D Lund, 2011). doi:10.1007/978-1-4419-9745-6

28. Fishler R, Hofemeier P, Etzion $Y$, et al. Particle dynamics and deposition in true-scale pulmonary acinar models. Sci Rep. 2015; 5: 1-11.

29. Park JD, Kim JK, Jo MS, et al. Lobar evenness of deposition/retention in rat lungs of inhaled silver nanoparticles: an approach for reducing animal use while maximizing endpoints. Part Fibre Toxicol. 2019; 16 : $1-10$.

30. Kreyling WG, Möller W, Holzwarth U, et al. Age-dependent rat lung deposition patterns of inhaled 20 nanometer gold nanoparticles and their quantitative biokinetics in adult rats. ACS Nano. 2018; 12 7771-7790.

31. Yang L, Feuchtinger A, Möller W, et al. Three-dimensional quantitative co-mapping of pulmonary morphology and nanoparticle distribution with cellular resolution in nondissected murine lungs. ACS Nano. 2018. doi:10.1021/acsnano.8b07524

32. Jakobsson JKF, Aaltonen HL, Nicklasson H, et al. Altered deposition of inhaled nanoparticles in subjects with chronic obstructive pulmonary disease. BMC Pulm Med. 2018; 18: 1-11.

33. Jain KK. in Drug Delivery Systems (ed. Jain, K. K.) 1-50 (Humana Press, 2008).

34. Dong M, Mürdter TE, Philippi C, et al. Pulmonary delivery and tissue distribution of aerosolized antisense 2'-0-Methyl RNA containing nanoplexes in the isolated perfused and ventilated rat lung. Eur J Pharm Biopharm. 2012; 81: 478-485.

35. Sakamoto A, Matsumaru T, Yamamura N, et al. Quantitative expression of human drug transporter proteins in lung tissues: Analysis of regional, gender, and interindividual differences by liquid chromatography-tandem mass spectrometry. J Pharm Sci. 2013; 102: 3395-3406.

36. Melguizo C, Prados J, Luque R, et al. Modulation of MDR1 and MRP3 gene expression in lung cancer cells after paclitaxel and carboplatin exposure. Int J Mol Sci. 2012; 13: 16624-16635.

37. Patton JS. Mechanisms of macromolecule absorption by the lungs. Adv Drug Deliv Rev. 1996; 19: 3-36.

38. Tseng CL, Wang TW, Dong GC, et al. Development of gelatin nanoparticles with biotinylated EGF conjugation for lung cancer targeting. Biomaterials. 2007; 28: 3996-4005.

39. Li R, Wang X, Ji Z, et al. The surface charge and cellular processing of covalently functionalized multiwall carbon nanotubes determine pulmonary toxicity. ACS Nano. 2013; 7: 2352-2368.

40. Modrzynska J, Berthing T, Ravn-Haren G, et al. Primary genotoxicity in the liver following pulmonary exposure to carbon black nanoparticles in mice. Part Fibre Toxicol. 2018; 15: 1-12.

41. Fromen CA, Robbins GR, Shen TW, et al. Controlled analysis of nanoparticle charge on mucosal and systemic antibody responses following pulmonary immunization. Proc Natl Acad Sci. 2014; 112: 488-493.

42. Fromen CA, Rahhal TB, Robbins GR, et al. Nanoparticle surface charge impacts distribution, uptake and lymph node trafficking by pulmonary antigen-presenting cells. Nanomedicine. 2017; 12: 677-687.

43. Ferdous Z, Al-Salam S, Greish YE, et al. Pulmonary exposure to silver nanoparticles impairs cardiovascular homeostasis: Effects of coating dose and time. Toxicol Appl Pharmacol. 2019; 367: 36-50.

44. Jeon S, Clavadetscher J, Lee DK, et al. Surface Charge-Dependent Cellular Uptake of Polystyrene Nanoparticles. Nanomaterials. 2018; 8: 1028.

45. Chen P, Zhang Z, Gu N, Ji M. Effect of the surface charge density of nanoparticles on their translocation across pulmonary surfactant monolayer: a molecular dynamics simulation. Mol Simul. 2018; 44: 85-93.

46. Labiris NR, Dolovich MB. Pulmonary drug delivery. Part I: Physiological factors affecting therapeutic effectiveness of aerosolized medications. Br J Clin Pharmacol. 2003; 56: 588-599.

47. Ruge CA, Schaefer UF, Herrmann J, et al. The interplay of lung surfactant proteins and lipids assimilates the macrophage clearance of nanoparticles. PLoS One. 2012; 7.

48. Hertel SP, Winter G, Friess W. Protein stability in pulmonary drug delivery via nebulization. Adv Drug Deliv Rev. 2015; 93: 79-94. 
49. Raunio H, Hakkola J, Hukkanen J, et al. Expression of xenobioticmetabolizing CYPs in human pulmonary tissue. Exp Toxicol Pathol 1999; 51: 412-7.

50. San Jose C, Cabanillas A, Benitez J, et al. CYP1A1 gene polymorphisms increase lung cancer risk in a high-incidence region of Spain: A casecontrol study. BMC Cancer. 2010; 10: 463.

51. Stücker I, Jacquet M, de Waziers I, et al. Relation between inducibility of CYP1A1, GSTM1 and lung cancer in a French population. Pharmacogenetics. 2000; 10: 617-627.

52. Chono S, Fukuchi R, Seki T, et al. Aerosolized liposomes with dipalmitoyl phosphatidylcholine enhance pulmonary insulin delivery. J Control Release. 2009; 137: 104-109.

53. Yhee JY, Im J, Nho RS. Advanced therapeutic strategies for chronic lung disease using nanoparticle-based drug delivery. J Clin Med. 2016; 5 jcm5090082.

54. Wu Z, Zou X, Yang L, et al. Thermosensitive hydrogel used in dual drug delivery system with paclitaxel-loaded micelles for in situ treatment of lung cancer. Colloids Surfaces B Biointerfaces. 2014; 122: 90-98.

55. Godugu C, Patel AR1, Doddapaneni R, et al. Inhalation delivery of Telmisartan enhances intratumoral distribution of nanoparticles in lung cancer models. J Control Release. 2013; 172: 86-95.

56. Xu PY, Kankala RK, Pan YJ, et al. Overcoming multidrug resistance through inhalable siRNA nanoparticles-decorated porous microparticles based on supercritical fluid technology. Int J Nanomedicine. 2018; 13: 4685-4698.

57. Kommareddy S, Amiji M. in Cellular Drug Delivery Principles and PRactices (eds. Robert Lu, D. \& Qie, S.) 181-215 (Humana Press, 2004).

58. Zhang L, Su H, Liu Y, et al. Enhancing solid tumor therapy with sequential delivery of dexamethasone and docetaxel engineered in a single carrier to overcome stromal resistance to drug delivery. J Control Release. 2019; 294: 1-16.

59. Akbarzadeh A, Rezaei-Sadabady R, Davaran S, et al. Liposome: Classification, preparation, and applications. Nanoscale Res Lett. 2013; 8: 1.

60. Jiang L, Li L, He X, et al. Overcoming drug-resistant lung cancer by paclitaxel loaded dual-functional liposomes with mitochondria targeting and pH-response. Biomaterials. 2015; 52: 126-139.

61. Liu C, Shi J, Dai Q, et al. In-vitro and in-vivo evaluation of ciprofloxacin liposomes for pulmonary administration. Drug Dev Ind Pharm. 2015 9045: 272-278.

62. Batrakova EV, Bronich TK, Vetro JA, et al. Polymer micelles as drug carriers. Nanoparticulates as drug carriers. 2006; 57-93. doi:10.1142/9781860949074_0005

63. Gupta A, Arora A, Manakshi A, et al. Nanotechnology and its applications in drug delivery : A review. WebmedCentral Int J Med Mol Med. 2012; 3: WMC002867.

64. Torchilin VP. Structure and design of polymeric surfactant-based drug delivery systems. J Control Release. 2001; 73: 137-172.

65. Wei X, Wang Y, Zeng W, et al. Stability influences the biodistribution, toxicity, and anti-tumor activity of doxorubicin encapsulated in PEGPE micelles in mice. Pharm Res. 2012; 29: 1977-1989.

66. Han W, Shi L, Ren L, et al. A nanomedicine approach enables codelivery of cyclosporin A and gefitinib to potentiate the therapeutic efficacy in drug-resistant lung cancer. Signal Transduct Target Ther. 2018; 3: 16 .

67. Zhang L, Chen Z, Yang K, et al. $\beta$-Lapachone and paclitaxel combination micelles with improved drug encapsulation and therapeutic synergy as novel nanotherapeutics for NQ01-targeted cancer therapy. Mol Pharm. 2015; 12: 3999-4010.
68. Myung JH, Roengvoraphoj $\mathrm{M}$, Tam KA, et al. Effective capture of circulating tumor cells from a transgenic mouse lung cancer model using dendrimer surfaces immobilized with anti-EGFR. Anal Chem. 2015; 87: 10096-10102.

69. Ryan GM, Kaminskas LM, Kelly BD, et al. Pulmonary administration of PEGylated polylysine dendrimers: Absorption from the lung versus retention within the lung is highly size-dependent. Mol Pharm. 2013; 10: 2986-2995.

70. Kaminskas LM, McLeod VM, Ryan GM, et al. Pulmonary administration of a doxorubicin-conjugated dendrimer enhances drug exposure to lung metastases and improves cancer therapy. J Control Release. 2014; 183: 18-26.

71. Liu J, Liu J, Chu L, et al. Novel peptide-dendrimer conjugates as drug carriers for targeting nonsmall cell lung cancer. Int J Nanomedicine. 2011; 6: 59-69.

72. Kumar S, Dilbaghi N, Saharan R, et al. Nanotechnology as emerging tool for enhancing solubility of poorly water-soluble drugs. Bionanoscience. 2012; 2: 227-250.

73. Abd Elwakil MM, Mabrouk MT, Helmy MW, et al. Inhalable lactoferrinchondroitin nanocomposites for combined delivery of doxorubicin and ellagic acid to lung carcinoma. Nanomedicine. 2018; 13: 20152035

74. Fosgerau K, Hoffmann T. Peptide therapeutics: Current status and future directions. Drug Discov Today. 2015; 20: 122-128.

75. Penchala SC, Miller MR, Pal A, et al. A biomimetic approach for enhancing the in vivo half-life of peptides. Nat Chem Biol. 2015; 11: 793-798.

76. Sarkar G, Curran GL, Sarkaria JN, et al. Peptide carrier-mediated noncovalent delivery of unmodified cisplatin, methotrexate and other agents via intravenous route to the brain. PLoS One. 2014; 9.

77. Yang W, Xia Y, Fang Y, et al. Selective cell penetrating peptidefunctionalized polymersomes mediate efficient and targeted delivery of methotrexate disodium to human lung cancer in vivo. Adv Healthc Mater. 2018; 7: 1701135.

78. Walker L, Perkins E, Kratz F, et al. Cell penetrating peptides fused to a thermally targeted biopolymer drug carrier improve the delivery and antitumor efficacy of an acid-sensitive doxorubicin derivative. Int J Pharm. 2012; 436: 825-832.

79. Videira M, Almeida AJ, Fabra A. Preclinical evaluation of a pulmonary delivered paclitaxel-loaded lipid nanocarrier antitumor effect. Nanomedicine Nanotechnology Biol Med. 2012; 8: 1208-1215.

80. Roa WH, Azarmi S, Al-Hallak MH, et al. Inhalable nanoparticles, a noninvasive approach to treat lung cancer in a mouse model. J Control Release. 2011; 150: 49-55

81. Kim I, Byeon HJ, Kim TH, et al. Doxorubicin-loaded porous PLGA microparticles with surface attached TRAIL for the inhalation treatment of metastatic lung cancer. Biomaterials. 2013; 34: 64446453.

82. Choi SH, Byeon HJ, Choi JS, et al. Inhalable self-assembled albumin nanoparticles for treating drug-resistant lung cancer. J Control Release. 2015; 197: 199-207.

83. Long JT, Cheang TY, Zhuo SY, et al. Anticancer drug-loaded multifunctional nanoparticles to enhance the chemotherapeutic efficacy in lung cancer metastasis. J Nanobiotechnology. 2014; 12: 37.

84. Tseng CL, Su WY, Yen KC, et al. The use of biotinylated-EGF-modified gelatin nanoparticle carrier to enhance cisplatin accumulation in cancerous lungs via inhalation. Biomaterials. 2009; 30: 3476-3485.

85. Lemarie E, Vecellio L, Hureaux J, et al. Aerosolized gemcitabine in patients with carcinoma of the lung: Feasibility and safety study. J Aerosol Med Pulm Drug Deliv. 2011; 24: 261-270. 
86. Ruiz-Ceja KA, Chirino YI. Current FDA-approved treatments for nonsmall cell lung cancer and potential biomarkers for its detection. Biomed Pharmacother. 2017; 90: 24-37.

87. BC Cancer Agency. Carboplatin. 2014; 1-9.

88. Rittmeyer A. Articles Atezolizumab versus docetaxel in patients with previously treated non-small-cell lung cancer (OAK): a phase 3, openlabel, multicentre randomised controlled trial. Lancet. 2017; 389: 255-265.

89. BC Cancer Agency. Bevacizumab. 2016; 1-10.

90. Cancer Care Ontario. Ceritinib. 2016; 1-13.

91. BC Cancer Agency. Paclitaxel. 2016; 1-10.

92. Wang X, Zhou J, Wang Y, et al. A phase I clinical and pharmacokinetic study of paclitaxel liposome infused in non-small cell lung cancer patients with malignant pleural effusions. Eur J Cancer. 2010; 46: 1474-1480.

93. Qu MH, Zeng RF, Fang S, et al. Liposome-based co-delivery of siRNA and docetaxel for the synergistic treatment of lung cancer. Int J Pharm. 2014; 474: 112-122.

94. Guo L, Fan L, Ren J, et al. Combination of TRAIL and actinomycin D liposomes enhances antitumor effect in non-small cell lung cancer. Int J Nanomedicine. 2012; 7: 1449-1460.

95. Li XT, He ML, Zhou ZY, et al. The antitumor activity of PNA modified vinblastine cationic liposomes on Lewis lung tumor cells: In vitro and in vivo evaluation. Int J Pharm. 2015; 487: 223-33.

96. Vasey PA,Kaye SB, Morrison R, etal.Phase I clinicaland pharmacokinetic study of PK1 [N-(2-Hydroxypropyl) methacrylamide copolymer doxorubicin]: First member of a new class of chemotherapeutic. Clin Cancer Res. 1999; 5: 83-94.

97. Li F, Li T, Cao W, et al. Near-infrared light stimuli-responsive synergistic therapy nanoplatforms based on the coordination of telluriumcontaining block polymer and cisplatin for cancer treatment. Biomaterials. 2017; 133: 208-218.

98. Das J, Das S, Paul A, et al. Assessment of drug delivery and anticancer potentials of nanoparticles-loaded siRNA targeting STAT3 in lung cancer, in vitro and in vivo. Toxicol Lett. 2014; 225: 454-464.

99. Wolinsky JB, Liu R, Walpole J, et al. Prevention of in vivo lung tumor growth by prolonged local delivery of hydroxycamptothecin using poly(ester-carbonate)-collagen composites. J Control Release. 2010; $144,280-287$.

100. Tang BC, Fu J, Watkins DN, et al. Enhanced efficacy of local etoposide delivery by poly(ether-anhydride) particles against small cell lung cancer in vivo. Biomaterials. 2010; 31: 339-344.

101. Wang G, Wang Z, Li C, et al. RGD peptide-modified, paclitaxe prodrug-based, dual-drugs loaded, and redox-sensitive lipidpolymer nanoparticles for the enhanced lung cancer therapy. Biomed Pharmacother. 2018; 106: 275-284.

102. Lowery A, Onishko H, Hallahan DE, et al. Tumor-targeted delivery of liposome-encapsulated doxorubicin by use of a peptide that selectively binds to irradiated tumors. J Control Release. 2011; 150: 117-124.

103. Patel AR, Chougule M, Singh M. EphA2 targeting pegylated nanocarrier drug delivery system for treatment of lung cancer Pharm Res. 2014; 31: 2796-2809.

104. Zhuang B, Du L, Xu H, et al. Self-assembled micelle loading cabazitaxel for therapy of lung cancer. Int J Pharm. 2016; 499: 146-155.

105. Shen J, Yin Q, Chen L, et al. Co-delivery of paclitaxel and survivin shRNA by pluronic P85-PEI/TPGS complex nanoparticles to overcome drug resistance in lung cancer. Biomaterials. 2012; 33: 8613-8624.

106. Gill KK, Nazzal S, Kaddoumi A. Paclitaxel loaded PEG5000 DSPE micelles as pulmonary delivery platform: Formulation characterization, tissue distribution, plasma pharmacokinetics, and toxicological evaluation. Eur J Pharm Biopharm. 2011; 79: 276-284.

107. Zhu JJ, Zhang XX, Miao YQ, et al. Delivery of acetylthevetin B, an antitumor cardiac glycoside, using polymeric micelles for enhanced therapeutic efficacy against lung cancer cells. Acta Pharmacol Sin. 2017; 38: 290-300.

108. Nidhi K, Indrajeet S, Khushboo M, et al. Hydrotropy: A promising tool for solubility enhancement: A review. Int J Drug Dev Res. 2011; 3: 26-33.

109. Zhong Q, Bielski ER, Rodrigues LS, et al. Conjugation to poly(amidoamine) dendrimers and pulmonary delivery reduce cardiac accumulation and enhance antitumor activity of doxorubicin in lung metastasis. Mol Pharm. 2016; 13: 2363-2375.

110. Kim I, Byeon HJ, Kim TH, et al. Doxorubicin-loaded highly porous large PLGA microparticles as a sustained- release inhalation system for the treatment of metastatic lung cancer. Biomaterials. 2012; 33: $5574-5583$

111. Xu C, Wang Y, Guo Z, et al. Pulmonary delivery by exploiting doxorubicin and cisplatin co-loaded nanoparticles for metastatic lung cancer therapy. J Control Release. 2019; 295: 153-163.

112. Feng T, Tian H, Xu C, et al. Synergistic co-delivery of doxorubicin and paclitaxel by porous PLGA microspheres for pulmonary inhalation treatment. Eur J Pharm Biopharm. 2014; 88: 1086-1093.

113. Rosière R, Van Woensel M, Mathieu V, et al. Development and evaluation of well-tolerated and tumor-penetrating polymeric micelle-based dry powders for inhaled anti-cancer chemotherapy. Int J Pharm. 2016; 501: 148-159.

114. Rosière R, Van Woensel M, Gelbcke $M$, et al. New folate-G grafted chitosan derivative to improve delivery of paclitaxel-loaded solid lipid nanoparticles for lung tumor therapy by inhalation. Mol Pharm. 2018; 15: 899-910.

115. Taratula 0 , Garbuzenko $\mathrm{OB}$, Chen $\mathrm{AM}$, et al. Innovative strategy for treatment of lung cancer: Targeted nanotechnology-based inhalation co-delivery of anticancer drugs and siRNA. J Drug Target. 2011; 19: 900-914.

116. Dhanda DS, Tyagi P, Mirvish SS, et al. Supercritical fluid technology based large porous celecoxib-PLGA microparticles do not induce pulmonary fibrosis and sustain drug delivery and efficacy for several weeks following a single dose. J Control Release. 2013; 168: 239-250.

117. Kabary DM, Helmy MW, Abdelfattah EA, et al. Inhalable multicompartmental phospholipid enveloped lipid core nanocomposites for localized mTOR inhibitor/herbal combined therapy of lung carcinoma. Eur J Pharm Biopharm. 2018; 130: 152-164. 